\title{
DIVERSIDAD CULTURAL Y ACCESO A LA INFORMACIÓN
}

COORDINADORA

Estela Morales Campos

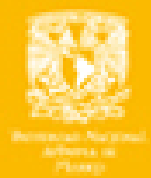

CUADERNOS DE INVESTIGACIÓN 9 
La presente obra está bajo una licencia de:

http://creativecommons.org/licenses/by-ncsa/3.0/deed.es MX

\section{(c) cointive}

Eres libre de:

(15)

copiar, distribuir y comunicar públicamente la obra

(D) hacer obras derivadas

Bajo las condiciones siguientes:

Atribución - Debes reconocer la autoría de la obra en los términos

especificados por el propio autor o licenciante.

No comercial - No puedes utilizar esta obra para fines comerciales.

Licenciamiento Reciproco - Si alteras, transformas o creas una obra a

partir de esta obra, solo podrás distribuir la obra resultante bajo una licencia igual a ésta.

Esto es un resumen fácilmente legible del: texto legal (de la licencia completa)

\section{En los casos que sea usada la presente obra, deben respetarse los términos especificados en esta licencia.}
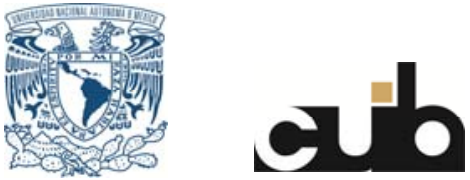
Diversidad cultural y acceso

a la información 


\title{
Diversidad cultural y acceso a la información
}

\author{
Coordinadora \\ Estela Morales Campos
}

Universidad Nacional Autónoma de México 2008 
HM851

D58

Diversidad cultural y acceso a la información / coordinadora, Estela Morales Campos. UNAM, Centro Universitario de Investigaciones Bibliotecológicas, 2008.

Primera reimpresión, 2009

p.xiii, 131 p. - (Cuadernos de Investigación ; 9) ISBN: 978-607-02-0753-2

1. Sociedad de la Información 2. Tecnología de la Información 3. Acceso a la Información 4. Multiculturalismo I. Morales Campos, Estela, coordinadora II. ser.

\section{Diseño de portada: Mario Ocampo Chávez}

Primera Edición, 2008

Primera Reimpresión, 2009

DR (C) UNIVERSIDAD NACIONAL AUTÓNOMA DE MÉXICO

Ciudad Universitaria, 04510, México, D.F.

Impreso y hecho en México

ISBN: 978-607-02-0753-2 


\section{Contenido}

\section{PResentación}

Estela Morales Campos. . . . . . . . . . . vii

$\operatorname{LOS}$ AUTORES $\ldots \ldots \ldots \ldots \ldots \ldots \ldots$

EL ROL DE LA BIBLIOTECA PÚBLICA FRENTE A LOS DISTINTOS ROSTROS DE LA DIVERSIDAD CULTURAL

Beatriz Casa Tirao $\ldots \ldots \ldots \ldots$

USOS SOCIALES DE INTERNET Y ACCESO A LA INFORMACIÓN POR PARTE DE COMUNIDADES MIGRANTES

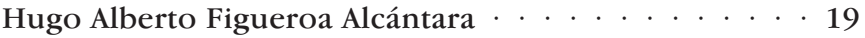

TOLERANCIA, POlíticas CULTURALES Y SOCIALES, Y MULTICULTURALISMO: DESAFíOS PROFESIONALES DE LOS SERVICIOS DE INFORMACIÓN José de Jesús Hernández Flores . . . . . . . . . . . . . . . 49

DIVERSIDAD CULTURAL Y BIBLIOTECAS PÚBLICAS

Rosa María Martínez Rider . . . . . . . . . . . . . . . . . 75

LAS SOCIEDADES MULTICULTURALES Y SU RELACIÓN CON LA BIBLIOTECOLOGÍA

Estela Morales Campos. . . . . . . . . . . . . . . . 103

ACuerdos de inVestigación. SEMinario PERMANENTE "BIBLIOTECOLOGÍA, INFORMACIÓN Y SOCIEDAD"

Homero Quezada Pacheco . . . . . . . . . . . . 125 


\section{Presentación}

II" n la actualidad, son cada vez más sofisticados el CDesarrollo y la innovación de tecnologías de la información, tanto las relacionadas con el rendimiento de este insumo como las vinculadas a su obtención y uso. En consecuencia, el margen de acción de los profesionales de la Bibliotecología ha tenido que extenderse, buscando, al mismo tiempo, una adaptación más eficaz en un entorno social que se modifica a cada instante. Ha sido necesario, además, tomar en cuenta los diversos contextos que exige un escenario inserto en una globalización creciente e irreversible; la economía, la política, la jurisprudencia, la ciencia, el arte y, en general, la cultura, exigen una perspectiva bibliotecológica que plantee enfoques inéditos y pautas creativas.

Así, fenómenos como el del multiculturalismo, cuya añeja existencia ha cobrado un intenso y renovado interés en el contexto de la globalización, influye notablemente en las maneras de concebir el 
ciclo de la información actual. Por otro lado, sucesos como el de las migraciones masivas a entornos geográficos de mayor desarrollo económico y social, han requerido una reevaluación de conceptos como los de identidad, diversidad y pluralismo; por ende, los servicios bibliotecarios se han visto requeridos a modificar y a adaptar una demanda informativa que exige atender a grupos humanos que manifiestan una gran amplitud de peculiaridades y características únicas.

En ese sentido, el compromiso de las bibliotecas públicas debe contribuir a que los usuarios, provenientes de cualquier región o comunidad cultural, satisfagan sus necesidades de información para que puedan integrarse de manera adecuada y fructífera en la sociedad en la que se encuentren. Asimismo, en el ámbito de los servicios de información, es conveniente que el establecimiento de programas y políticas culturales funcionen en beneficio de la integración de los distintos sectores de agrupaciones humanas cada vez más conscientes de su pluralidad. Por otra parte, la adecuada orientación en el uso de Internet puede ser muy provechosa en la actual distribución informativa, que alcanza prácticamente cualquier ámbito del conocimiento y el quehacer humano. 
Estas preocupaciones fueron abordadas recientemente en el seminario permanente de "Bibliotecología, Información y Sociedad" y los resultados han permitido conformar el presente volumen. Cada una de las colaboraciones expone una faceta particular en torno a alguno de dichos temas y, en conjunto, configuran un panorama que contribuye a fortalecer el vínculo del multiculturalismo y los servicios de información.

En esta ocasión, hemos reunido trabajos de Beatriz Casa, Hugo Alberto Figueroa, José de Jesús Hernández, Rosa María Martínez Rider y Estela Morales, cuyos puntos de vista continúan explorando algunos de los nexos establecidos entre nuestra profesión y el entorno social contemporáneo.

Esperamos que nuestras aportaciones brinden espacios para enriquecer los debates relativos a estos temas y para propiciar nuevas discusiones en el campo de acción de la Bibliotecología y los Estudios de la Información. 


\section{Los autores}

\section{Beatriz Casa Tirao}

Es licenciada en Bibliotecología por la Universidad de Buenos Aires. Estudió la Maestría en Educación de la Comunidad en el Ministerio de Educación de la Provincia de Buenos Aires, así como la Maestría en Enseñanza Superior en la UNAM. Se ha desempeñado como docente en diversos niveles del sistema educativo, donde también ha ejercido cargos directivos. Ha sido asesora de niveles directivos en el área de Bibliotecología y profesora de carrera en el Colegio de Bibliotecología y Estudios de la Información en la Facultad de Filosofía y Letras de la UNAM. Es autora de libros y de numerosos capítulos de libros y artículos en revistas, con temas de Bibliotecología, Sociología y Educación.

\section{Hugo Alberto Figueroa Alcántara}

Licenciado en Bibliotecología por la Universidad Nacional Autónoma de México. Inició su carrera docente en 1985 en el Colegio de Bibliotecología de 
la Facultad de Filosofía y Letras, UNAM, del cual fue Coordinador de 1990 a 1998. Desde 1996 a la fecha (2007) es Profesor de Carrera de Tiempo Completo. Ha publicado 10 libros y 30 artículos o capítulos de libros. Se ha distinguido por promover significativamente la titulación de los alumnos. $\mathrm{Ha}$ dirigido 115 trabajos de titulación, ya presentados en examen profesional. Ha sido responsable o corresponsable de Proyectos PAPIME y PAPIIT de la UNAM. Imparte los cursos de Sistema de Clasificación Dewey, Sistema de Clasificación LC, Teoría y Técnica Bibliográfica, Industrias Editorial y de la Información y Seminario de Investigaciones Bibliotecológicas 1 y 2. Fue miembro del Comité Académico del Colegio de Bibliotecología de 2003 a 2006. Es Consejero Técnico Propietario (2006-2012) de la FFyL, representante de los profesores del Colegio de Bibliotecología. Sus líneas de investigación son: Relaciones Bibliográficas y Cibercultura.

\section{José de Jesús Hernández}

Es licenciado en Biblioteconomía de la Escuela Nacional de Biblioteconomía y Archivonomía (ENBA), donde es profesor desde 1992. En sus cursos, destaca la relación entre la Bibliotecología y la sociedad. Estudió la maestría en Bibliotecología en la Universidad Nacional Autónoma de México 
Diversidad cultural y acceso a la información

(UNAM), institución en la cual se desempeña como Técnico Académico Titular "C" del Instituto de Investigaciones Estéticas. Es miembro del Seminario Bibliotecología, Información y Sociedad y autor de varios artículos; asimismo, ha participado con ponencias en foros sobre la disciplina a nivel nacional e internacional.

\section{Rosa María Martínez Rider}

Es licenciada en Biblioteconomía por la Universidad Autónoma de San Luis Potosí y maestra en Educación por la Universidad Pedagógica Nacional. Actualmente (2008) es estudiante del doctorado en Biblioteconomía y Documentación en la Universidad Complutense de Madrid. Es profesora-investigadora de tiempo completo, nivel VI, en la Escuela de Bibliotecología e Información de la UASLP, donde, además, ocupa el cargo de directora. Entre otras líneas de investigación, ha desarrollado: "Epistemología de las Ciencias de la Información"; "Patrimonio documental", y "Currículum y pedagogía en ciencias de la información”. Sus publicaciones se han concentrado, fundamentalmente, en el área de ciencias de la Información y en la de educación en México. 


\section{Estela Morales Campos}

Es doctora en Estudios Latinoamericanos y maestra en Bibliotecología por la Universidad Nacional Autónoma de México, institución en la cual se desempeña como Coordinadora de Humanidades, como Investigadora Titular "C" y como profesora del posgrado en Bibliotecología y Estudios de la Información. Desde 1989 pertenece al Sistema Nacional de Investigadores. En 2006, fue nombrada miembro regular de la Academia Mexicana de Ciencias. Es autora de 15 libros (entre los más recientes se hallan: La diversidad informativa latinoamericana en México; Infodiversidad, globalización y derecho a la información; Infodiversidad y cibercultura. Globalización e información en América Latina; y Forjadores e impulsores de la bibliotecología latinoamericana), así como de más de cien artículos publicados en revistas tanto nacionales como extranjeras. En la UNAM, ha sido directora del Centro Universitario de Investigaciones Bibliotecológicas (1985-1993), secretaria académica de la Coordinación de Humanidades (1993-1995) y directora del Centro Coordinador y Difusor de Estudios Latinoamericanos (a partir de agosto de 2007, Centro de Investigaciones sobre América Latina y el Caribe). 


\title{
El rol de la biblioteca pública frente a los distintos rostros de la diversidad cultural
}

\author{
BEATRIZ CASA TIRAO
}

\section{Introducción}

Cuando nos internamos en el tema de la diversiUdad entre los seres humanos, nos damos cuenta que éste no constituye el argumento propicio para una telenovela ni tampoco un tema que deba prestarse para alimentar la demagogia de los grupos de poder. La diversidad no es eso ni muchas otras cosas, pero sí es lo que nos permite comprender que existen diferencias entre los seres humanos, las que no suponen que unos sean mejores o peores que otros, simplemente son distintos. En los últimos tiempos el asunto la diversidad ha sido traído a colación frecuentemente y en diversas instancias, especialmente en el campo de las ciencias culturales pero, a pesar de ello, el contenido y significación del concepto ha sido poco explorado. 
Vale la pena examinar la etimología de la palabra "diversidad", la cual proviene del latín divertere, que significa lo diferente, lo que por distintas razones se aparta del camino que sigue la mayoría. Éste es el sentido lato del término, al que regresaremos más tarde.

Si se proyecta el concepto de diversidad al campo de la cultura, debemos tener presente, en primer lugar, qué significa este segundo concepto que abordamos. La expresión "cultura" se ha prestado y se presta a numerosas interpretaciones de diferente contenido. Con frecuencia el término es referido, más que a otras instancias, a actividades que tienen que ver con las artes y con las letras. Así, quienes poseen conocimientos en estas áreas son considerados individuos "cultos" pero, en realidad, cultura no es eso. La sociología y la antropología social han demostrado que el concepto de cultura es muy amplio y abarca la vida y el quehacer particular de los diferentes grupos humanos, lo cual permite afirmar que es cultura admirar un cuadro de Picasso y que también lo es comer con las manos o invocar a los dioses mediante rituales considerados "primitivos". Esta posición da sustento a la definición que he diseñado y que habitualmente empleo en mis trabajos de investigación y en la cual se afirma que "Cultura es el conjunto de elementos que son producto de la acción humana, así como el pensar, el 
El rol de la biblioteca pública frente a los distintos rostros ...

sentir y el actuar de los seres humanos en cada generación, más la herencia social que la misma recibió de las generaciones anteriores". Esta definición permite comprender la cohesión que la cultura determina en cada grupo humano cuyos miembros se identifican entre sí a través de compartir las diversas instancias que la propia cultura les ofrece, entre otras una identidad que los distingue.

\section{La diversidad cultural}

Múltiples grupos humanos han desarrollado sus propias culturas y éstas les han dado la posibilidad de caracterizarse de una forma determinada, diferente a la del resto de la humanidad, en el tiempo y en el espacio. Estas culturas han sufrido embates a través de los siglos. En ocasiones han permanecido relegadas; en otras, pareciera que han sido borradas del mapa cultural y, por fin, en otros casos permanecieron latentes a la espera de demostrar que no habían sido vencidas por las culturas imperiales que en todos los tiempos han ejercido su poder de penetración, de absorción y mimetización de otras culturas.

Cuestiones incidentales determinan que culturas diversas se encuentren y operen en escenarios compartidos y esto se traduce en el fenómeno de la multiculturalidad, que no supone necesariamente una interrelación cultural sino que expresa, más bien, la existencia de algunas culturas en un grupo hetero- 
géneo. Esto expresa, más que una integración, una suma de elementos.

Según algunos autores, los mundos culturales se originan en la globalización y se construyen como multiculturalidad por migraciones $y$, en general, por la movilidad de los grupos de población. La multiculturalidad tiene sus raíces en el origen de cada uno de los pueblos del mundo, con sus creaciones propias, sus tradiciones y sus formas de organización. Este tipo de análisis lleva a la observación no sólo de las creaciones propias de un grupo humano, sino también de las condiciones sociales, favorables o no, para crear y vivir en la multiculturalidad.

Una forma más avanzada de la integración de las culturas es la interculturalidad y se refiere al encuentro de culturas diversas para observarse, entenderse mutuamente y conocerse cada vez mejor. Ese encuentro cultural está relacionado con la armonización de las relaciones humanas, lo que permite pensar que este entendimiento supone una evolución de las sociedades en el terreno de la comprensión y de la empatía. La interculturalidad permite reflejar la dinámica social y formular el objetivo de nuevas síntesis socioculturales.

Por último, el concepto de transculturalidad ofrece un enfoque diferente en el tema de la diversidad cultural. La palabra fue acuñada en el siglo 
El rol de la biblioteca pública frente a los distintos rostros ...

pasado por el investigador cubano Fernando Ortiz quien la propuso para denominar el sentido dinámico de los procesos de transacciones interculturales. A partir de ello es posible comprender los fenómenos originados en la incorporación de las novedades provenientes de otros universos culturales con los que pueda entrar en contacto una cultura determinada. Las culturas creadas por unos individuos se alimentan de otras culturas creadas por otros individuos y se produce entonces el fenómeno del intercambio de experiencias culturales o transculturación.

La diversidad cultural se ha hecho más relevante en la actualidad en razón del desarrollo de los medios de comunicación y del aumento de las posibilidades de movilización que hoy existen, al punto de que la UNESCO, en 2001, emitió la Declaración Universal de la Diversidad Cultural donde la califica como patrimonio común de la humanidad. En esta Declaración destacan la necesidad de garantizar la interacción armoniosa y la convivencia de las personas y de los grupos así como las políticas que favorecen estas instancias. ${ }^{1}$

Por otro lado, el Informe Mundial de la UNESCO sobre las Sociedades del Conocimiento

1 Declaración Universal de la UNESCO sobre la Diversidad Cultural. París, UNESCO, 2001. 
señala que la diversidad cultural enriquece la vida de las sociedades y constituye uno de los motores importantes para promover el desarrollo social integral. $^{2}$

Ziang Xinsehng, presidente del Consejo Ejecutivo de la UNESCO y viceministro de educación de China, expresaba recientemente que "Nuestro futuro en este planeta sólo puede ser un futuro compartido y para conseguirlo no tenemos más materiales que el respeto y la comprensión, una comprensión cada vez mayor de los otros y de nuestra diversidad".

No se olvidan, en este rubro de la diversidad cultural, las migraciones internas que someten a diferentes culturas a individuos de un mismo país, ni tampoco se deja de lado la cuestión indígena respecto de la cual cabe recordar la Declaración del Encuentro Indígena Interamericano Preparatorio de la Cumbre Mundial ${ }^{4}$ de la Sociedad de la Información en la cual los indígenas reclaman su dere-

2 Informe Mundial de la UNESCO sobre las Sociedades de Conocimiento. París, UNESCO, 2005.

3 Discurso de clausura de la Reunión 174 del Consejo Ejecutivo de la UNESCO. 13 de abril de 2006.

4 Declaración del Congreso Indígena Iberoamericano Preparatorio de la Cumbre Mundial de la Sociedad de la Información. Brasilia, 8-10 oct., 2005. 
El rol de la biblioteca pública frente a los distintos rostros ...

cho a participar en la sociedad de la información y en el empleo de la tecnología.

Hasta acá en lo que atañe a las formas académicas o sistemáticas, por así decirlo, de denominar las expresiones de la diversidad, pero existen otras formas de diferencias y diversidades. Así, por ejemplo, los grupos discriminados por razones como son las de género, por capacidades físicas diferentes, tendencias sexuales, portación de algunas enfermedades, etcétera, son transformados también en grupos diversos, diferentes, distintos... y marginados.

\section{La biblioteca pública en el nuevo escenario}

El panorama anteriormente descrito muestra que las sociedades modernas van en camino de transformarse en verdaderos crisoles de culturas. La gente emigra, los grupos humanos se desplazan y llevan consigo los rasgos de su propia cultura. Por otro lado, grupos emergentes reclaman un lugar digno en la sociedad en la que se desarrollan. Esto es lo que constituye los distintos rostros de la diversidad cultural y permite vislumbrar, y de hecho desde ya percibir, interrelaciones sociales difíciles y la necesidad urgente de abrir espacios de comprensión, tolerancia y entendimiento.

En este punto es donde cabe plantear la pregunta, desde nuestra perspectiva profesional y académica, acerca de cuál es el rol que ha de desempeñar 
la biblioteca pública, la más ligada al quehacer social, ante un panorama novedoso y complejo.

En los grupos inmigrantes, la diversidad cultural incluye, generalmente, la diversidad lingüística, la cual no debería ser considerada aparte de la primera (diversidad cultural y lingüística, como suele denominarse este tema), porque la lengua es un hecho cultural en sí mismo.

El primer punto a considerar es el carácter de la biblioteca pública. Desde mi punto de vista, los objetivos de la misma deben ser enriquecidos notablemente. Sin olvidar el tradicional fomento del hábito de la lectura planteado por la UNESCO desde los inicios, la biblioteca pública debe comprometerse con objetivos sociales, económicos y educativos. Además, es necesario que los profesionales de la $\mathrm{Bi}$ bliotecología comprendamos que la biblioteca pública y la biblioteca en general son un instrumento más en el concierto de las instituciones comunitarias que tienen la misión de fomentar el desarrollo de los grupos humanos a los cuales atienden. Por lo tanto, el éxito de cada una de esas instituciones depende de la capacidad de integración que posea y del entendimiento que sean capaces de suscitar y ejercer entre ellas.

La diversidad cultural por inclusión de nuevos grupos humanos en sociedades ya establecidas, ocasiona el surgimiento de necesidades que deben ser 
El rol de la biblioteca pública frente a los distintos rostros ...

atendidas para que los individuos que llegan puedan tener una inserción provechosa en la nueva sociedad en la que vivirán. Como coadyuvante directo de la educación en cualquiera de sus formas, la biblioteca asume un rol protagónico en estas circunstancias siempre, como antes se dijo, en un trabajo integral con otras instituciones. Destaca en el nuevo escenario la biblioteca pública que, por sus características propias, la acercan a la comunidad y a los diferentes grupos que la integran.

La biblioteca pública es un escenario donde se trasuntan los cambios sociales y, de esta manera, tiene presente las necesidades comunitarias, así como las de los grupos de lectores que, a su vez, integran comunidades particulares como los estudiantes, los trabajadores de determinados sectores, amas de casa y otros, a los cuales se debe atender con las acciones afines a la actividad lectora a partir de la cual surge la relación con otras actividades y servicios bibliotecarios que tienen que ver con la vida diaria de los individuos y con sus requerimientos en todos los sentidos.

La información en fenómenos de diversidad cultural debe entenderse en dos sentidos: en primer lugar, como aquella dirigida a los individuos que se insertan en culturas diferentes a la propia y tiene como objetivo permitir que conozcan las características, ventajas y problemas que tiene el grupo so- 
cial al que habrán de pertenecer, pero también sirve para proporcionarles materiales de lectura e información acerca de su propio país o región de origen, con el objeto de evitar el olvido y mitigar el dolor del desarraigo que siempre existe $y$, además y no pocas veces, las vivencias de un rechazo inicial en la nueva situación.

En otro sentido, y no menos importante, la información que proporciona la biblioteca pública se dirige a la comunidad originaria del lugar del que se trate, con el objeto de que abra su mente y su espíritu a la presencia de otras personas con una cultura distinta, diversa, la cual debe ser respetada de la misma manera que la propia. Se trata, en cualquier caso, de hacer de la lectura un hábito cultural que facilite la comprensión entre individuos de orígenes y culturas diferentes. Esta labor de apertura hacia el campo del entendimiento entre los individuos a través de la lectura como vehículo de información y conocimiento, le compete en gran medida a la biblioteca pública y se complementa con las funciones que a ésta le son propias, especialmente la de extensión bibliotecaria, la cual ofrece múltiples recursos para obtener el fin que se busca y representa, también, una buena oportunidad para estimular el trato y acercamiento entre los integrantes de la comunidad. 
El rol de la biblioteca pública frente a los distintos rostros ...

Si se tienen en cuenta las distintas actividades que las bibliotecas públicas pueden llevar a cabo para satisfacer las necesidades de usuarios pertenecientes a grupos donde están representadas culturas diversas y, a la vez, a individuos en situaciones que dependen de sus propias condiciones particulares, se entiende que la tarea es compleja. La existencia de sociedades establecidas en las cuales irrumpen grupos de personas que provienen de culturas diferentes, supone un desafío en cuanto a la convivencia intercultural en la cual cada grupo conserva sus propios rasgos culturales pero, a la vez, debe aceptar al "otro" y su cultura, así como las formas de convivencia y respeto, condición sine qua non entre los individuos y entre éstos y las instituciones. Como un ejemplo, puede señalarse que las leyes deben ser conocidas en una etapa temprana a través de proyectos destinados a los niños inmigrantes, así como a los adultos en igual situación. La biblioteca pública parece la institución indicada para desarrollar esta labor destinada a permitir que estos nuevos integrantes de la comunidad puedan internalizar aquellos conocimientos que les permitirán establecer lazos dinámicos de relaciones humanas en su nueva situación para compartir espacios con sentido comunitario, aceptar las nuevas condiciones de vida, siempre que éstas no atenten contra su dignidad, y comenzar a integrarse a las pautas culturales de la nueva sociedad. 
La biblioteca pública es capaz de hacer una contribución importante a través del fomento de la lectura en grupo sobre temas pertinentes al caso y que den lugar a la posterior discusión e intercambio de opiniones y propuestas. Es cierto que la biblioteca pública es un recurso importante en situaciones de diversidad cultural, pero hay que tener en cuenta que no es el único y que no tiene todas las posibilidades, sino que necesita integrarse con otras instituciones en un verdadero proceso de desarrollo de la comunidad. Es posible afirmar que "El papel de la biblioteca pública examinado desde el punto de vista que ofrece el concepto de desarrollo local y del consecuente y necesario desarrollo de la comunidad, parece obvio, ya que la biblioteca pública es, por su propia esencia, una institución social cuya presencia es inexcusable en estas circunstancias". 5

La biblioteca pública puede enriquecer sus actividades dirigidas a solucionar los problemas que plantea la diversidad cultural con actividades entre las que se pueden sugerir las siguientes:

5 Beatriz Casa Tirao. "La inserción de la biblioteca pública en los procesos de desarrollo local en el marco de la globalización". En Congreso Nacional de Bibliotecas Públicas, 2. Guadalajara, 23-25 sep. 2002. Memoria. México, CONACULTA, Gobierno de Jalisco, 2003. p.93. 
El rol de la biblioteca pública frente a los distintos rostros ...

- Acciones que permitan un mejor conocimiento de los diversos grupos que se reúnen en la comunidad, poniendo de relieve los intereses de unos y otros, el porqué de los mismos y el significado que tienen.

- Conocimiento a través de la lectura, el relato y la dramatización, de la literatura y poesía del grupo inmigrante y del grupo receptor, con la posibilidad de un fructífero intercambio.

- Talleres donde los grupos participantes conozcan las características y valores del país del otro, así como el significado que para cada uno de ellos tienen. En esto se incluye el conocimiento de la historia, geografía, formas de vida, creencias, leyendas, etcétera.

- En general, el fomento de todas aquellas acciones que permitan crear relaciones de tolerancia, comprensión y respeto entre individuos formados en culturas diferentes.

Para terminar, a partir de lo anterior es posible afirmar lo que a continuación se enumera:

- La biblioteca pública reúne en sí misma las características que le permiten contribuir a asegurar factores de convivencia entre seres provenientes de culturas diversas y con distintas experiencias de vida. A partir de ello se afirma aún más el carácter educativo que posee y que la transforma en un agente importante para la for- 
mación de los individuos y el desarrollo de los países.

- Pueden mencionarse de manera puntual las funciones generales que corresponden a la biblioteca pública ante el fenómeno de la diversidad cultural señalando que debe poner a disposición de los distintos grupos étnicos, lingüísticos y culturales en general, los servicios que les permitan a todos disfrutar de las mismas oportunidades.

- Corresponde también a la biblioteca pública fomentar la idea de la diversidad como una realidad existente e, igualmente, promover que no sea un factor de enfrentamientos sino, por el contrario, una motivación para la interrelación y el conocimiento mutuo.

- Una función principal de la biblioteca pública es la de coadyuvar en la lucha contra el analfabetismo, de cualquier tipo que éste sea, y promover incansablemente el hábito y el gusto por la lectura entre los miembros de la comunidad a la cual atiende, ejercicio que debe ir más allá de la lectura rutinaria para asumir objetivos más altos como los de obtener y crear conocimiento y fomentar valores personales y sociales.

- En lo que se refiere a las tecnologías de la información, la biblioteca pública debe asegurar el acceso a las mismas a todos los usuarios, en el entendimiento previo de que dichas tecnologías 
El rol de la biblioteca pública frente a los distintos rostros ...

son instrumentos para obtener conocimiento y saber, con los cuales es posible llegar a la comprensión del mundo, de la vida y de los otros.

- Es necesario diseñar un nuevo modelo de biblioteca pública que, sin dejar de lado algunos de los objetivos tradicionales, los transforme e integre aquellos que responden a las necesidades actuales, entre ellas las propias de la diversidad cultural. En este punto vale la pena recordar lo expresado por Paulo Freire, el gran pedagogo brasileño, que al tocar el tema de la alfabetización de adultos señala que "La comprensión crítica de la alfabetización, que incluye la comprensión igualmente crítica de la lectura, exige la comprensión crítica de la biblioteca". ${ }^{6}$

- Nuevos aires deben también correr en la formación de los bibliotecólogos. De una vez por todas, quienes tenemos esa responsabilidad de hacerlo debemos ponernos de acuerdo sobre los valores que deben inspirar a la profesión, acerca también de la necesidad de participar en la construcción de un nuevo humanismo que permita equilibrar las demandas y las respuestas sociales. Los planes de estudio deben tender a formar no solamente profesionales de la bibliotecología

6 Paulo Freire. La importancia de leer y el proceso deliberación. $16^{\mathrm{a}}$. ed. México, Siglo XXI, 2004. p. 94. 
sino seres sensibles y comprometidos socialmente. Esto, entre otras cosas, promoverá la posibilidad de que desde nuestra área de conocimiento se sumen esfuerzos para la solución de problemas vitales.

- Como profesionales de la información y a partir del estudio de la diversidad, debemos crear un foro para la unidad, la unidad del diálogo, de la experiencia mutua, del respeto recíproco entre los que son diferentes, sin llegar a convertirse, sin embargo, en un foro para la unidad de un determinado concepto del mundo o de un orden impuesto. Crear, en definitiva, puentes para la comprensión.

Para terminar, por el momento, con el tratamiento de este tema, hago un alto para recordar el pensamiento de un grande del folclore latinoamericano, Atahualpa Yupanqui, cuando al expresar su canto solidario manifiesta, simplemente que "el otro es uno 'mesmo' con la piel de otro".

\section{Bibliografía}

García Canclini, Néstor. Culturas híbridas. Estrategias para entrar y salir de la modernidad. México, Grijalbo, 1990.

Giordan, Henri. "Sociedades multiculturales y multiétnicas". En Documentos de debate, no. 5, París, UNESCO, 1995. 
El rol de la biblioteca pública frente a los distintos rostros ...

González, Alfonso. "La actuación de la biblioteca pública en Cataluña respecto a los inmigrados del Tercer Mundo”. Boletín de la Asociación Andaluza de Bibliotecas, no. 31, abr.-jun., 2003.

González, Alfonso. "La biblioteca, uno de los protagonistas de la integración de la población inmigrante". Jornada sobre bibliotecas juveniles y escolares, $5^{\text {a }}$. Salamanca. Salamanca, Fundación F. Ruipérez, 1998.

Grumberg, George. Articulación de la diversidad. Quito, Biblioteca Abya Yala, 1995.

IFLA. Sección de servicios bibliotecarios para poblaciones multiculturales: directrices para servicios bibliotecarios. 2. ed. La Haya, 1998.

Kymlicka, Will. Ciudadanía multicultural. Barcelona, Paidós, 1996.

Perceval, J. M. Nacionalismo, xenofobia y racismo en la comunicación: una perspectiva histórica. Barcelona, Paidós, 1995.

Touraine, Alain. ¿Podemos vivir juntos? México, Fondo de Cultura Económica, 2000.

Tudesco, Juan Carlos. El nuevo pacto educativo. Educación, competitividad y ciudadanía en la sociedad moderna. Madrid, Alauda Anaya, 1995.

UNESCO. L'UNESCO et la question de la diversité culturelle: Bilan et stratégies, 1946-2004. Étude realisée a partir d' un choix de documents officiels. París, UNESCO, 2004. 


\title{
Usos sociales de Internet y acceso a la información por parte de comunidades migrantes
}

\author{
Hugo Alberto FigueroA \\ ALCÁNTARA
}

\section{Introducción}

$\mathrm{U}$

no de los fenómenos más notorios de nuestra sociedad contemporánea es el de la progresiva e irreversible globalización, proceso en principio económico pero que implica un entrelazamiento a escala planetaria de prácticamente todas las actividades humanas: económicas, políticas, sociales, culturales, científicas, tecnológicas y de comunicación, etcétera. En tal marco, los diversos vínculos entre los individuos, las comunidades y la sociedad en su conjunto se tornan cada vez más complejos y con mayores grados de interconectividad, generándose nuevos códigos, símbolos y significados, así 
como inéditas representaciones, prácticas y vínculos sociales y culturales. ${ }^{1}$

En este fenómeno de la globalización, la comunicación y la información juegan un papel vital, por lo que tienen una estrecha relación con el nacimiento, desarrollo e impresionante efecto de un medio tecnológico y de comunicación que con el paso del tiempo y a nivel mundial se ha transformado en uno de los componentes sociales fundamentales de nuestras vidas: Internet, sobre todo por su capacidad para distribuir el poder de la información por todas las esferas de la actividad humana, convirtiéndose así en paradigma de la base tecnológica y de comunicación del modelo de organización que caracteriza a la sociedad actual: la red. ${ }^{2}$

Los elementos explicados con anterioridad conforman el sustento de nuevos modelos sociales, culturales y científicos: sociedad red, ${ }^{3}$ cultura de las

1 Alberto Melucci. Vivencia y convivencia: teoría social para una era de la información. Madrid: Trotta, 2001. p. 46-51.

2 Manuel Castells. La galaxia Internet: reflexiones sobre Internet: empresa y sociedad. Barcelona: Areté, 2001. p. 15.

3 Manuel Castells. La sociedad red. México: Siglo XXI, 1999. 590 p.; Cebrián, Juan Luis. La red. Madrid: Santillana: Suma de Letras, 2000. $282 \mathrm{p}$. 
Usos sociales de Internet y acceso a la información por parte ...

redes ${ }^{4}$ y ciencia de las redes, ${ }^{5}$ entre otros paradigmas.

En estos modelos complejos, representados de diversas formas por la interrelación y organización a través de redes, las expresiones de identidad y los usos sociales de Internet y acceso a la información por parte de comunidades migrantes adquieren nuevos significados, sentidos y trascendencia, que desafían los modelos socio-culturales y económico-políticos dominantes y que buscan una mayor actuación e intervención de la gente sobre su vida, entornos y cotidianeidad. ${ }^{6}$

4 Michael Joyce. Othermindedness: the emergence of network culture. Ann Arbor: The University of Michigan Press, 2001. 252 p.; Taylor, Mark C. The moment of complexity: emerging network culture. Chicago: The University of Chicago Press, 2001. 340 p.; Kerckhove, Derrik. Inteligencias en conexión. Barcelona: Gedisa, 1999. 253. p.; Lévy, Pierre. L'intelligence collective: pour une antbropologie du cyberspace. Paris: La Découverte, 1997. 245 p.

5 Albert-Lászlo Barabási. Linked: the new science of networks. Cambridge: Perseus, 2002. 280 p.; Buchanan, Mark. Nexus. New York: W.W. Norton, 2002. 235 p.; Watts, Duncan J. Six degres: the science of a connected age. New York: W.W. Norton, 2003. 368 p.; Strogatz, Steven. Sync: the emerging science of spontaneous order. New York: Hyperion, 2003. 338 p.

6 Manuel Castells. El poder de la identidad. México: Siglo XXI, 1999. p. 23-24 
Así, cobran gran ímpetu en los tiempos actuales, sobre todo en el marco de la conformación de la sociedad red, las propuestas sociales y culturales basadas en la identidad, ${ }^{7}$ así como en la diferencia ${ }^{8}$ y sus efectos, en una de las tendencias más visibles en la actualidad: el surgimiento y consolidación de comunidades migrantes con presencia en múltiples lugares de un país, región o del mundo, y el empleo cada vez más singular e innovador que hacen de Internet y otras tecnologías de comunicación e información para comunicarse, intercambiar información, conformar vigorosas redes sociales y fortalecer su identidad. ${ }^{9}$

En la permanente construcción y reacomodo de estos novedosos modelos identitarios de las comunidades migrantes dentro de la sociedad red, juegan un papel vital Internet y otras tecnologías de información y comunicación, así como las instituciones

7 Juan Antonio Dianes Rubio. Identidad y ética: la constitución ética de "sí mismo" en la filosofía de Paul Ricoeur. Cádiz, España: el Autor, 2003. 442 p. Tesis Doctoral presentada en la Facultad de Filosofía y Letras de la Universidad de Cádiz. Versión en formato PDF, obtenida a través de Dissertation Abstracts (UMI).

8 Míroslav Mílovic. Comunidad de la diferencia. Granada: Universidad de Granada, 2004. 143 p.

9 Identidad y ciudadanía: un reto a la educación intercultural (Margarita Bartolomé Pina, coordinadora). Madrid: Narcea, 2002. $195 \mathrm{p}$. 
Usos sociales de Internet y acceso a la información por parte ...

sociales vinculadas íntimamente con los ciclos sociales de la información y el conocimiento, tales como las bibliotecas, los archivos y los museos, entre otras.

Bajo esta perspectiva es que se considera trascendente, desde un enfoque bibliotecológico, el análisis de los usos sociales de Internet y el acceso a la información por parte de comunidades migrantes, en el marco de la sociedad red y la función que los bibliotecólogos y las bibliotecas pueden desempeñar en la consolidación de modelos de trabajo que favorezcan la comunicación, los flujos de información y el fortalecimiento de la identidad y las redes sociales en estos grupos sociales.

Para tal fin, el trabajo se divide en tres partes. $\mathrm{La}$ primera explica el papel que actualmente tiene Internet como medio de comunicación y generador de espacios sociales en la sociedad red. En la segunda, se analizan las características de fenómenos tan complejos como la identidad colectiva, las comunidades migrantes y su vinculación con la acción colectiva y los nuevos movimientos sociales en el entorno de la sociedad red. La tercera parte está dedicada a la reflexión y ejemplificación sobre la importancia crucial que las bibliotecas y los bibliotecólogos tenemos, en el contexto de motivar y promover los usos sociales de Internet y el acceso a la información por parte de comunidades migran- 
tes en la sociedad red, así como la profunda responsabilidad y compromiso sociales que tenemos, como bibliotecólogos, para confluir en la construcción de sistemas sociales más democráticos, plurales, tolerantes, flexibles y multiculturales, tal como las corrientes históricas mundiales, heterodoxas y críticas, ${ }^{10}$ demandan, cada vez con mayor insistencia y urgencia, ${ }^{11}$ tanto a nivel general como en el campo de la bibliotecología. ${ }^{12}$

\section{Internet, medio de comunicación y genera- dor de espacios sociales en la sociedad red}

Existe un consenso cada vez mayor acerca de que hoy día se percibe una transición de la sociedad industrial a la sociedad red (conocida también como sociedad del conocimiento o sociedad de la información, o bien, caracterizada por algunos de sus rasgos esenciales mediante conceptos como sistema

10 Carlos Antonio Aguirre Rojas. Antimanual del mal historiador, $o$, ¿Cómo hacer hoy una buena bistoria crítica? México: Contrahistorias, La otra mirada de Clío, 2004. 141 p.

11 Dominique Wolton. La otra mundialización: los desafíos de la cobabitación cultural global. Barcelona: Gedisa, 2004. 194 p.

12 Toni Samek. "Internet and intention: an infrastructure for progressive librarianship". En IJIE: International Journal of Information Ethics. Vol. 2 (11/2004). Revista en línea disponible en: http://container.zkm.de/ijie/ijie/no002/ijie_002_23_samek. pdf. Fecha de consulta: 3 de marzo de 2007. 
Usos sociales de Internet y acceso a la información por parte ...

mundo, reflexividad y construcción de códigos simbólicos). ${ }^{13}$ En este proceso, Internet, como medio tecnológico y de comunicación, es el motor fundamental de una serie de cambios vertiginosos en esta era, simbolizada por la importancia vital de la información, de tal manera que también podemos denominar a la sociedad red como era de la información. Internet forma ya parte indisoluble del tejido social de la vida cotidiana y ha implicado cambios profundos en nuestras formas de trabajar, aprender, convivir, informarnos y relacionarnos. Así, Internet genera nuevos espacios sociales que caracterizan a la sociedad red: redes, no tan sólo tecnológicas sino sociales, conectividad, comunicación horizontal de muchos a muchos, complejidad y velocidad cada vez mayor de los flujos de información. ${ }^{14}$ Transitamos, en esencia, de una sociedad industrial basada en la producción de bienes materiales a una sociedad fundamentada en la producción de bienes de información. Los rasgos primordiales que se identifican en esta transformación son

13 Benjamín Tejerina. Multiculturalismo, movilización social y procesos de construcción de la identidad en el contexto de la globalización. 2004. Documento PDF disponible en: http://www.ces.fe. uc.pt/publicacoes/oficina/187/187.pdf. Fecha de consulta: 3 de marzo de 2007.

14 Castells, Manuel. La galaxia Internet: reflexiones sobre Internet: empresa y sociedad. Barcelona: Areté, 2001. p. 15-17. 
Diversidad cultural y acceso a la información

la disminución de la producción material y el aumento de la producción de información y signos culturales. ${ }^{15}$

Pueden destacarse varios elementos que explican la profunda trascendencia de Internet en todas las actividades humanas y, por consecuencia, su impacto tan fundamental en la configuración de la sociedad red. Por ejemplo, la utilización de tecnologías de carácter público, su estructura descentralizada y la cultura libertaria que desde sus inicios caracterizó a este medio. Internet es, sobre todo, un nuevo medio de comunicación eminentemente horizontal, que posibilita profundamente el intercambio de ideas, información y conocimientos entre personas que conforman diferentes tipos de comunidades y redes sociales. A través de Internet, identificamos el surgimiento y desarrollo inédito de nuevos espacios sociales de alcance global, en el que conviven millones de persona de contextos sociales, culturales, políticos, económicos, etcétera, muy heterogéneos. Se trata de la creación y desarrollo de nuevas esferas de intercambios sociales que afecta de manera directa o indirecta a un porcentaje cada vez mayor de la población mundial y

15 Alberto Melucci. Nomads of the present: social movements and individual needs in contemporary society. Philadelphia, Penn.:

Temple University Press, 1989. p. 45 
Usos sociales de Internet y acceso a la información por parte ...

que está provocando la aparición de nuevas formas de sociabilidad, basadas en modelos de red. ${ }^{16}$

Comprender estos paradigmas emergentes de organización, sistemas de intercambio de información, símbolos culturales, valores y creencias, basados en modelos de red, y dentro de este contexto, el papel cada vez más protagónico que juegan las comunidades migrantes para fortalecer su identidad, comunicarse y acceder a la información, puede aportarnos datos interesantes acerca de las problemáticas a las que, desde nuestro quehacer bibliotecológico, hemos de afrontar y trabajar creativamente cada vez con mayor frecuencia.

\section{Identidad colectiva y comunidades migran- tes en la sociedad red}

Dentro del universo social cada vez más complejo e interconectado, característico de la sociedad red, una de las dimensiones más interesantes es la relativa a la construcción de la identidad. En el ámbito de la sociedad red, conformada en gran medida por el fenómeno Internet, la identidad pasa a ser el resultado de un proceso singular y reflexivo de construcción por parte de los actores sociales. Los indi-

16 Pau Contreras. Me llamo Kohfam: identidad hacker, una aproximación antropológica. Barcelona: Gedisa, 2003. p. 26-27. 
viduos, vinculados de múltiples maneras en red y pertenecientes a varias redes comunitarias (entre ellas las generadas por su afinidad social, cultural, étnica, lingüística, etcétera), tienen ante sí un enorme número de opciones y toman decisiones conscientes acerca de lo que son, las comunidades y grupos con los que se sienten identificados y lo que pretenden llegar a ser. Este proceso de construcción de la identidad tiene un carácter marcadamente social, colectivo, reflexivo, simbólico y se encuentra estrechamente vinculado con un concepto clave en el contexto de la era de la información o sociedad red: la acción colectiva. ${ }^{17}$

De acuerdo con lo anterior, en el marco de la sociedad red, los modelos de acción colectiva, vinculados estrechamente con los nuevos movimientos sociales, tales como la conformación de comunidades migrantes, los movimientos multiculturales, ecologistas, de género, o los movimientos alternativos, identificados bajo el nombre genérico de otro mundo es posible, entre otros, se basan en la construcción consciente e interconectada de la identidad para representar la acción colectiva.

17 Alberto Melucci. Vivencia y convivencia: teoría social para una era de la información. Madrid: Trotta, 2001. p. 166-173 
Usos sociales de Internet y acceso a la información por parte ...

Estos nuevos movimientos sociales, dentro de los cuales se enmarcan los movimientos de constitución de comunidades migrantes, que trabajan y se desarrollan en estructuras de redes, constituyen, al interior de la sociedad red, verdaderos laboratorios de cultura y son generadores de códigos culturales alternativos a los dominantes, desafíos simbólicos a los límites del poder que intentan dar soluciones al problema y papel del individuo y las comunidades en la sociedad global.

Sin duda, una cualidad notable de los nuevos movimientos sociales y de la conformación de la sociedad red, y las redes de la sociedad, ${ }^{18}$ es su carácter de global/local que asocia intereses específicos de áreas localizadas a movimientos que a la vez se entrelazan con objetivos y utopías a escala mundial, que implican amplias zonas geográficas y diferentes culturas y sociedades y, por ende, un entorno primordialmente multicultural, enmarcado en nuevas dimensiones del tiempo y espacio sociales. Al respecto, un concepto fundamental es el de glocalización, que alude al hecho de que en lo sucesivo lo

18 Fernando Mires. "Comunicación: entre la globalización y la glocalización: la sociedad de redes (o las redes de la sociedad)". En Chasqui: Revista Latinoamericana de Comunicación. No. 67 (septiembre de 1999). Revista en línea disponible en: http://www. comunica.org/chasqui/mires67.htm. Fecha de consulta: 3 de marzo de 2007. 
global es inseparable de lo local, tal como lo ha mostrado Castells, ${ }^{19}$ al analizar las múltiples interconexiones entre lo global y lo local, y la influencia mutua de lo local en lo global. Un pensamiento muy frecuente en diversos movimientos sociales es, por ejemplo: Pensar globalmente y actuar localmente. ${ }^{20}$

En tal contexto, un concepto de gran importancia es el de redes comunitarias, dentro de las cuales tienen una presencia y acción cada vez más significativas las redes de comunidades migrantes, que responden a nuevas formas de asociación, identidad y acción colectivas de la era de la información y de la interconectividad. Se trata de un término genérico, bajo el cual se definen las diferentes formas y prácticas que a través del uso de Internet configuran el tejido social, cultural, económico y político, de las sociedades contemporáneas.

Así, estos nuevos movimientos sociales, expresados en redes comunitarias, pueden concebirse

19 Manuel Castells. La sociedad red. México: Siglo XXI, 1999. 590 p.; Castells, Manuel. El poder de la identidad. México: Siglo XXI, 1999. 495 p.; Castells, Manuel. Fin de milenio. México: Siglo XXI, 1999. $446 \mathrm{p}$.

20 Maximiliano Dueñas Guzmán. Globalización y comunicación alternativa. 2004. Disponible en: http://www.comminit.com/ la/pensamientoestrategico/lasth/lasld -806.html. Fecha de consulta: 3 de marzo de 2007 . 
Usos sociales de Internet y acceso a la información por parte ...

como formas de acción colectiva, basados en la solidaridad, comprometidos en un conflicto y cuyas acciones intentan construir modelos alternativos de organización, ayuda mutua, comunicación e información. ${ }^{21}$

Dentro de esta dinámica social, el concepto de el de identidad colectiva es un elemento crucial que explica por qué se generan estas acciones colectivas.

El concepto de identidad colectiva permite explicar los mecanismos que motivan a las personas para participar en grupos de movimientos sociales. La identidad colectiva es un proceso de naturaleza social y psicológica, que vincula a los individuos con un grupo a través de una serie de interacciones que tienen como eje primordial la actividad del movimiento social. La identidad colectiva genera fuertes vínculos entre los individuos y el grupo, de tal modo que los individuos participantes tienen diversos intereses en común. ${ }^{22}$ Sin duda, en tal entor-

21 Alberto Melucci. Nomads of the present: social movements and individual needs in contemporary society. Philadelphia, Penn.: Temple University Press, 1989. p. 28.

22 Michael D Ayers. Collectiveldentity.org: collective identity in online and offline feminist activist groups. Thesis, Masters of Science in Sociology, Faculty of Virginia Polytechnic Institute and State University, 2001. p. 2. Documento PDF disponible en: http:// scholar.lib.vt.edu/theses/available/etd-06112001-151759/unrestricted/thesis_final.pdf. Fecha de consulta: 3 de marzo de 2007. 
no, un aspecto fundamental del ser humano, y que lo diferencia plenamente de otras especies, es su eterna lucha por el reconocimiento, ${ }^{23}$ pieza clave en la comprensión de los movimientos multiculturales actuales, dentro de los cuales juegan un papel protagónico las comunidades migrantes.

En tal entorno, la irrupción de Internet como nuevo escenario de relación e interacción social es la base, en gran medida, del surgimiento de nuevos actores colectivos, movimientos sociales, proyectos de acción colectiva y generación de identidades colectivas que construyen un escenario inédito en la sociedad red. En este desarrollo de nuevos actores sociales en la cual algunos movimientos sociales se están transformando, el funcionamiento en red y el uso intensivo de Internet representan rasgos muy distintivos. Muchos de ellos se autodenominan redes e incluso constituyen redes de movimientos. ${ }^{24}$

En este sentido, un aspecto crucial que merece destacarse es que el tejido comunicativo, representado por Internet, crea tejido social y favorece nuevas alternativas de recursos y acciones para los mo-

23 Axel Honneth. La lucha por el reconocimiento: por una gramática moral de los conflictos sociales. Barcelona: Crítica: Grijalbo Mondadori, c1997. 230 p.

24 Un libro excelente al respecto es: Víctor Marí Sáez (Coordinador). La Red es de todos: cuando los movimientos sociales se apropian de la red. Madrid: Editorial Popular, 2004. 277 p. 
Usos sociales de Internet y acceso a la información por parte ...

vimientos sociales, entre ellos los promovidos por comunidades migrantes. Los flujos comunicativos facilitados a través de Internet configuran nuevas dinámicas organizativas y propician el surgimiento de redes sociales, con atributos peculiares de acción e identidad colectiva, que les dan singularidad a sus reivindicaciones, a la vez que les permite entrelazarse, en estructura de red, a otros movimientos y causas.

De acuerdo con las características explicadas previamente, a continuación se analizan y proponen una serie de acciones que, desde una perspectiva bibliotecológica, se pueden llevar a cabo para promover los usos sociales de Internet y el acceso a la información por parte de comunidades migrantes, aprovechando las facilidades que brinda Internet y los modelos de organización, comunicación e información social basados en redes, característicos de nuestras vivencias y convivencias, propias de nuestro tránsito a una sociedad red.

\section{Acciones del bibliotecólogo para promover los usos sociales de Internet y el acceso a la información por parte de comunidades mi- grantes}

Las bibliotecas, al ser instituciones sociales imprescindibles de los ciclos sociales de la información y del conocimiento, y al ser parte integral de los pro- 
cesos educativos, sociales, culturales, entre otros, debe responder cabalmente a las demandas de una sociedad global cada vez más multicultural, resultado, entre otros aspectos, de los flujos migratorios en aumento percibidos en todo el mundo y, en este sentido, dar la pauta para promover cambios positivos, por ejemplo para coadyuvar en el desarrollo, la comunicación y el acceso a la información por parte de comunidades migrantes. ${ }^{25}$

Desde tal perspectiva, una pregunta crucial es: ¿Qué debemos hacer como actores sociales para que nuestros acciones bibliotecarias influyan en la conformación de una sociedad más plural y multicultural? ¿Qué acciones debemos emprender para apoyar el desarrollo social, cultural, educativo, etcétera, de las comunidades migrantes que crecen a nuestro alrededor?

$\mathrm{Al}$ respecto, un principio absolutamente fundamental y determinante en esta perspectiva bibliotecológica es que nosotros, como bibliotecólogos, asumamos plenamente nuestra responsabilidad social y hagamos realmente trabajo comunitario, en beneficio de redes y movimientos sociales, bien en-

25 Sandra Ríos Valderrama. "This trend called diversity". En Library Trends. No. 49 (Summer 2000). p. 203-211; También: Alice Roobin. "We the people: one nation, a multiculturaly society”. En Library Trends. No. 49 (Summer 2000). p. 8-10. 
Usos sociales de Internet y acceso a la información por parte ...

tendido, propositivo y positivo, que coadyuve en la construcción de un mundo mejor, más tolerante, justo y multicultural, estableciendo una serie de acciones que posibiliten el bien común, por lo menos en nuestro radio de alcance, pero si estas acciones se interconectan con otras similares, ganaremos mucho en cuanto a impacto local/global.

No hay que olvidar también que, dentro del universo social de la información, las actividades profesionales que realizamos para "[...]localizar, analizar e interpretar la información nos colocan en una posición privilegiada con respecto a otros, desde aquellos que no cuentan con los medios necesarios para tener acceso a la información, hasta quienes sí los poseen, pero carecen de elementos para analizar y comprender los contenidos." 26 Por tal motivo, a partir de nuestra posición, tenemos la posibilidad de emprender acciones que favorezcan los procesos de construcción de identidad y de movimientos sociales tales como los realizados por comunidades

26 Hugo Alberto Figueroa Alcántara y García Durán, Samira. "Vivencia y convivencia en el universo editorial y de la información”. En Figueroa Alcántara, Hugo Alberto y César Augusto Ramírez Velázquez (Coordinadores). Recursos bibliográficos y de información. México: UNAM, Facultad de Filosofía y Letras, Dirección General de Asuntos del Personal Académico, 2006. p. 131. 
Diversidad cultural y acceso a la información

migrantes, a favor de una sociedad más abierta, plural y democrática. ${ }^{27}$

A partir de estas premisas, vale la pena destacar y analizar los siguientes rubros, que ejemplifican el tipo de acciones que el bibliotecólogo puede emprender para promover los usos sociales de Internet y el acceso a la información por comunidades migrantes, en un entorno de redes y movimientos sociales.

Ante todo, para lograr resultados positivos, los bibliotecólogos debemos desarrollar una sensibilidad eminentemente social y comprometernos a servir firmemente a todo tipo de comunidades, incluidas las comunidades migrantes. Sin esa visión y ese compromiso no lograremos acciones políticas, sociales y culturales trascendentes, las diversas comunidades no se sentirán consideradas, no se fijarán metas $\mathrm{y}$, finalmente, no se invertirán recursos para desarrollar colecciones y servicios orientados a comunidades migrantes. ${ }^{28}$

27 Hugo Alberto Figueroa Alcántara y García Durán, Samira. Ibid. p. 131.

28 Jens Ingemann Larsen, Jacobs, Deborah L. y Van Vlimmeren, Ton. Multiculturalidad en la biblioteca: cómo pueden servir las bibliotecas públicas a las poblaciones multiculturales. Barcelona: Fundación Bertelsmann, 2004. p. 12. 
Usos sociales de Internet y acceso a la información por parte ...

En relación específica con las comunidades migrantes dentro de una localidad, otro aspecto crucial es el conocimiento profundo de la naturaleza y peculiaridades de la comunidad general, qué grupos están representados en la comunidad y en qué cantidad. Datos demográficos disponibles a través de la web y otros recursos de información, pero también información obtenida a través de cuestionarios y otros instrumentos aplicados en bibliotecas, son de indudable utilidad. Esto resulta vital para poder conocer las características de la comunidad con más detalle, así como sus necesidades de información, y de esta manera poder planear mejor las colecciones y servicios. ${ }^{29}$

También es muy importante destacar las funciones que pueden realizar las bibliotecas en una sociedad multicultural, constituida por diversas comunidades migrantes. Un ambiente bibliotecario favorable a la conformación de redes sociales multiculturales consolidadas debe propiciar, entre otros aspectos, que grupos de culturas distintas disfruten de su legado cultural en su propio idioma, a través de textos, grabaciones sonoras, videos, DVD, etcétera; sepan lo que está ocurriendo en sus regiones o países natales gracias a libros, periódicos, revistas,

29 Jens Ingemann Larsen, Jacobs, Deborah L. y van Vlimmeren, Ton. Ibid. p. 15-16. 
Internet y otros recursos de información; puedan comunicarse a través de correo electrónico, sitios web ad-hoc, portales orientados a la interacción de redes sociales, estaciones de radio comunitarias a través de la web, etcétera; aprendan y practiquen la lengua materna de sus padres, el idioma predominante del país o región en que se vive y otros idiomas de interés cultural, disponiendo en las bibliotecas de mediatecas idóneas para la práctica de diversos idiomas; encuentren su lugar en la sociedad ofreciéndoles información sobre la comunidad, guiándoles y ayudándoles a acceder a los recursos y servicios que necesitan; la propia biblioteca sea escenario de festivales, exposiciones, ciclos de cine, etcétera, donde tengan cabida los intereses y necesidades de diferentes comunidades migrantes, para conocerse mejor entre todos, comprender las afinidades y diferencias y generar un ambiente más plural y tolerante. ${ }^{30}$

Con base en tales elementos de carácter general, los siguientes ejemplos ilustrarían las acciones que podemos emprender para promover los usos sociales de Internet y el acceso a la información por parte de comunidades migrantes, mediante modelos de redes tecnológicas y sociales, donde el bibliote-

30 Jens Ingemann Larsen, Jacobs, Deborah L. y van Vlimmeren, Ton. Ibid. p. 16-17. 
Usos sociales de Internet y acceso a la información por parte ...

cólogo y las bibliotecas juegan o pueden jugar un papel muy importante.

Un caso muy ilustrativo e interesante es el desarrollado por la Toronto Public Library a través de su portal NeresConnect, ${ }^{31}$ el cual permite acceder a un gran número de periódicos de todas partes del mundo y en muy diversos idiomas, así como su portal Multicultural Connections, ${ }^{32}$ donde ofrece una gama muy amplia de servicios y recursos multiculturales, íntimamente vinculados con las necesidades reales de las diversas comunidades migrantes, por ejemplo: información general en quince idiomas diferentes, dirigida a los que recién han llegado a Canadá, con el propósito de resaltarles el gran valor que tiene la biblioteca en el entorno multicultural donde confluyen diversas comunidades migrantes; disponibilidad de intérpretes en diferentes idiomas, a través de teléfonos ubicados en las bibliotecas; cómo leer sitios de Internet en distintos alfabetos e idiomas; así como amplios recursos de información sobre servicios dirigidos a las comunidades migrantes, tales como aspectos relati-

31 Toronto Public Library. NewsConnect. 2006. Disponible en: http://newsconnect.tpl.toronto.on.ca/. Fecha de consulta: 3 de marzo de 2007.

32 Toronto Public Library. Multicultural Connections. 2006. Disponible en: http://www.torontopubliclibrary.ca/mul_index.jsp. Fecha de consulta: 3 de marzo de 2007. 
vos a ciudadanía, inmigración, facilidades para el aprendizaje del inglés o del francés, ayuda legal y médica, etcétera.

En tal sentido, podemos destacar que una de las funciones vitales de las bibliotecas en un contexto multicultural es que las distintas comunidades migrantes sepan lo que está ocurriendo en sus países o regiones de origen gracias al acceso a libros, periódicos, revistas, música, películas, etcétera, así como el acceso mismo de esos materiales, o de otro tipo de recursos de información a través de Internet, etcétera, por una parte, y por la otra, es de primordial importancia dotar de información concreta y útil acerca de los servicios locales, instituciones educativas apoyo legal, médico, etcétera. Por ello, resulta perentorio que las bibliotecas realicen acciones inmediatas para ofrecer a través de sus portales, sitios web y otro tipo de medios, este tipo de alternativas a las comunidades migrantes circundantes. En tal contexto, es de capital importancia que los bibliotecólogos estén atentos a las innovaciones tecnológicas y convergencia de medios que a nivel global se perciben y que pueden derivar en un beneficio local de gran impacto social. También es crucial que identifiquen, sistematicen, interpreten y difundan las propuestas y proyectos expresados en la web, que puedan ser de utilidad para alentar y promover 
Usos sociales de Internet y acceso a la información por parte ...

los usos sociales de Internet y el acceso a la información por parte de las comunidades migrantes.

Otro ejemplo muy ilustrativo, relativo al acceso a la información por comunidades migrantes, y que podrían aprovechar plenamente las bibliotecas a muy bajo costo o incluso sin cargo para la biblioteca si algunos usuarios donan suscripciones virtuales, lo representa PressDisplay, ${ }^{33}$ un servicio en línea muy interesante que ofrece acceso a más de los 200 diarios de mayor prestigio provenientes de 55 países, en su alfabeto, idioma, formato, diseño y paginación originales, con sistemas de navegación, marcado, despliegue y lectura muy intuitivos y cómodos e incluso con la posibilidad de descargarse a la computadora y leerse fuera de línea en la casa o en el camino a otros lugares. Así como éste, existen varios servicios de esta naturaleza, que pueden perfectamente abrir el abanico de opciones ofrecidas a comunidades migrantes desde la biblioteca.

Otro caso de gran relevancia, emanado de las propias comunidades, pero donde los bibliotecólogos y las bibliotecas pueden jugar un papel trascendente en la identificación, organización, difusión,

33 PressDisplay. Read newspapers here: 200 newspapers from 55 countries. 2006. Disponible en: http://www.pressdisplay.com/ pressdisplay/viewer.aspx. Fecha de consulta: 3 de marzo de 2007. 
Diversidad cultural y acceso a la información

promoción y ejemplificación como modelos de proyectos en la web que interconectan a grupos de personas que pueden estar separados geográficamente pero que los unen multitud de vínculos culturales e identitarios, se encuentra representado por la emergencia y cada vez mayor impacto de sitios web dedicados a comunidades, pueblos y naciones específicos, que ha permitido establecer fuertes lazos de contacto, ayuda, gestión, solidaridad entre familias y comunidades que se quedan en los lugares de origen e integrantes que por diversos motivos (trabajo, estudio, etcétera) deben pasar largas temporadas en otros países, en nuestro caso, como destino predominante, diversas regiones de Estados Unidos. Algunos ejemplos admirables, que bien pueden servir de modelos para que otras comunidades emprendan sus propios proyectos son los portales o sitios web de San Martín de Bolaños (Jalisco), ${ }^{34}$ y Tlaltenango (Zacatecas); ${ }^{35}$ respecto a otros países, son ejemplos excelentes Patria grande

34 San Martín de Bolaños: tierra de costumbre y tradición. 2006. Disponible en: http://www.sanmartinjalisco.com/sanmartin. htm. Fecha de consulta: 3 de marzo de 2007.

35 Tlaltenango.com: Zacatecas, México. 2006. Disponible en: http: //www.tlaltenango.com/. Fecha de consulta: 3 de marzo de 2007. 
Usos sociales de Internet y acceso a la información por parte ...

(argentinos en España) ${ }^{36}$ y Redota: uruguayos en el exterior. ${ }^{37}$

Todos estos proyectos tienen en común una función eminentemente social, comunitaria y permiten generar complejos vínculos de identidad, información, unión, localización, solidaridad y gestión. También coinciden en diversos servicios y secciones que se ofrecen, por ejemplo: foros, chats, opciones para correo electrónico, directorios de personas y entidades, noticias e historia de la comunidad, anuncios de fiestas familiares, de la comunidad, del pueblo o del país, vínculos a sitios similares, enlaces a información legal, de inmigración, o bien a estaciones de radio, periódicos, etcétera, de la región, entre otras posibilidades. Algunos estudios interesantes sobre esta temática son: Tequio: identidad y comunicación entre migrantes oaxaqueños, por Genoveva Flores Quintero; ${ }^{38}$ Los migrantes, la identi-

36 Patria grande: argentinos en España. 2006. Disponible en: http:// www.patriamadre.com/content/1.asp. Fecha de consulta: 3 de marzo de 2007.

37 Redota: uruguayos en el exterior. 2006. Disponible en: http:// www.redota.com/.Fecha de consulta: 3 de marzo de 2007.

38 Genoveva Flores Quintero. Tequio: identidad y comunicación entre migrantes oaxaqueños. Amérique Latine Histoire et Mémoire, no. 8-2004 - Médias et migrations en Amérique Latine. En línea. Disponible en: http://alhim.revues.org/document423. html. Fecha de consulta: 2 de marzo de 2007. 
dad y las nuevas tecnologías, por Óscar Imbaquingo, ${ }^{39}$ el cual trata acerca de comunidades migrantes ecuatorianas; Las comunidades virtuales de migrantes en los Estados Unidos, su impacto y su vinculación con el lugar de origen: El caso de San Martín de Bolaños, México, por Miriam Cárdenas Torres. ${ }^{40}$

Otra alternativa que desde la biblioteca puede promover el fortalecimiento de redes comunitarias en comunidades migrantes, así como el acceso a la información, es el desarrollo de estaciones de radio comunitarias, incluso a través de Internet, tal y como de manera profunda se explica con casos reales a través del mundo en Radio apasionados: experiencias de radio comunitaria en el mundo ${ }^{41}$ y Secreto a voces: radio, NTICs e interactividad. ${ }^{42}$

39 Óscar Imbaquingo. 2007. Los migrantes, la identidad y las nuevas tecnologías. Disponible en: http://www.elecuatoriano. com/. Fecha de consulta: 3 de marzo de 2007.

40 Cárdenas Torres, Miriam. "Las comunidades virtuales de migrantes en los Estados Unidos, su impacto y su vinculación con el lugar de origen: el caso de San Martín de Bolaños, México”. En Carlos Massé (coord.), La complejidad de las ciencias sociales en la sociedad de la información y la economía del conocimiento: trastocamiento objetual y desarrollo informacional en Iberoamérica. México: El Colegio Mexiquense, 2005.

41 Radio apasionados: experiencias de radio comunitaria en el mundo (editor, Bruce Girard). Edición digital, 2002. Disponible en: http:// alhim.revues.org/document423.html. Fecha de consulta: 3 de marzo de 2007. 
Usos sociales de Internet y acceso a la información por parte ...

En el ámbito bibliotecológico, bajo las mismas ideas de estrechar fronteras y propiciar el diálogo entre comunidades migrantes, destaca, entre otros, el sitio web de la Library of Congress, Meeting of frontiers = Встреча на границах ${ }^{43}$ que ofrece, para fines académicos y de investigación, aunque también para el uso del público en general, de Estados Unidos, Rusia y cualquier parte del mundo, una biblioteca digital bilingüe y multimedia relacionada con múltiples temas comunes entre Estados Unidos y Rusia.

Por otra parte, si partimos del principio de que no hay nada mejor que sensibilizar a los niños desde la más temprana edad, para que convivamos en armonía en un entorno cada vez más multicultural, resulta de gran importancia el proyecto de la University of Maryland, International Children's Digital Library: a Library for the World's Children, ${ }^{44} \mathrm{el}$

42 Secreto a voces: radio, NTICS e interactividad (editor, Bruce Girard). Edición digital, 2004. Editado con el apoyo de la FAO. Disponible en: http://comunica.org/apasionados/pdf/radioapas ionados.pdf. Fecha de consulta: 3 de marzo de 2007.

43 Library of Congress. Meeting of frontiers = Bcmpena на гранииах. 2006. Disponible en: http://frontiers.loc.gov/intldl/mtfhtml/ mfhome.html. Fecha de consulta: 3 de marzo de 2007.

44 University of Maryland. International Children's Digital Library: a Library for the World's Children. 2006. Disponible en: http://www.icdlbooks.org/index.shtml. Fecha de consulta: 3 de marzo de 2007. 
cual tiene el propósito de crear, a nivel mundial, la biblioteca digital multicultural más completa y representativa de libros para niños, en muy diversos idiomas y de todas partes del planeta.

En el trabajo bibliotecológico, otra vertiente fundamental vinculada con aspectos dirigidos a comunidades migrantes es la de la organización bibliográfica y de información, que permita un acceso multilingüe en los catálogos bibliográficos, sobre todo en lo concerniente a las interfaces de los catálogos en línea, así como al acceso mediante encabezamientos de materia. Un ejemplo muy interesante al respecto es el proyecto europeo MACS (Multilingual Access to Subjects), ${ }^{45}$ el cual tiene como propósito establecer catálogos en línea que permitan al usuario realizar las búsquedas mediante encabezamientos de materia en inglés, francés o alemán, según la preferencia personal, y que se recuperen los documentos relacionados con la temática indagada, independientemente de su catalogación original. En este proyecto se pretende interconectar diferentes catálogos europeos.

45 Luis Bermello Crespo. "Tendencias de desarrollo de los lenguajes de encabezamientos de materia en las bibliotecas". En Revista Acimed. Vol. 9, no. 2 (2001). Revista en línea disponible en: http://bvs.sld.cu/revistas/aci/vol9_2_02/aci03201. htm. Fecha de consulta: 3 de marzo de 2007. 
Usos sociales de Internet y acceso a la información por parte ...

En Estados Unidos y América Latina también existe un interés creciente por dotar de accesos multilingües a los catálogos bibliográficos en línea, como un medio para favorecer la disponibilidad de colecciones a diversas comunidades migrantes. Un ejemplo que refleja esta tendencia es el libro $S A L S A$ de tópicos = subjects in SALSA: Spanish and Latin American subject access, ${ }^{46}$ donde se recogen distintas experiencias al respecto, desarrolladas en Estados Unidos y América Latina, incluido México.

Finalmente, vale la pena comentar que, como sucede con los casos previamente tratados, hay multitud de ejemplos, pero ante todo lo que se desea destacar es que, con el análisis e interpretación de este tipo de fenómenos emergentes en nuestra sociedad interconectada, podemos desarrollar una mayor sensibilidad y compromiso social para, desde nuestros campos de acción profesional y cotidiana, realizar tareas que redunden en un reconocimiento a los cambios vertiginosos que en materia multicultural estamos protagonizando $\mathrm{y}$ presenciando cada vez con mayor frecuencia y cercanía, como es el caso de la presencia creciente

46 David Miller y Martínez Arellano, Filiberto Felipe (Editors). SALSA de tópicos = subjects in SALSA: Spanish and Latin American subject access. Chicago: American Library Association, 2006. 
de comunidades migrantes en nuestros entornos cercanos.

Ante todo, quizá el reto más fuerte que se nos presenta, como disciplina y profesión, es modificar nuestro paradigma mental, cultural y social, respecto a un conjunto de elementos radicalmente cambiantes y complejos, que confluyen en la denominada sociedad red. En nuestras manos y voluntad se encuentran, en gran medida, los sueños, proyectos y resultados que podamos alcanzar. Para ello es de vital importancia pasar del discurso teórico, necesario sin duda, a una serie de acciones colectivas, interconectadas en todas las direcciones posibles con otros proyectos institucionales, así como con redes comunitarias sociales, entre ellas las de diversas comunidades migrantes, que mantienen la esperanza de construir un mundo más humano, plural, multicultural y justo. En nosotros mismos se encuentran los fundamentos, principios e ideales para realizarlo. Las acciones concretas que realicemos, aunque pequeñas en alcance aparentemente, si se interconectan y se crean extensas y sólidas redes de solidaridad pueden redundar en grandes cambios de dimensiones planetarias. 


\title{
Tolerancia, políticas culturales y sociales, y multiculturalismo: desafíos profesionales de los servicios de información
}

\author{
JOSÉ DE JESÚS HERNÁNDEZ FLORES
}

\begin{abstract}
[1/1 fenómeno del multiculturalismo, en la actua$\Longrightarrow$ lidad, puede hacer a las naciones presa fácil del caos. Es un proceso que representa un problema social por la mezcla de diversos elementos sociales interrelacionados entre sí; factores como, por ejemplo, política, educación y el mismo Estado. En suma, la falta de unas políticas públicas, sociales, culturales y educativas se conjuga con la indefinición de las mismas, y con una falta de visión en su planeación y un inadecuado diseño en su instrumentación. Todo lo anterior se agudiza por la carencia de continuidad; en conclusión, los beneficios son poco visibles ante las demandas de necesidades que presenta la sociedad moderna.
\end{abstract}


Las políticas, en teoría, deberían reportar beneficio para todos los niveles de la sociedad, promover la integración de individuos y grupos e incluir a todos sin importar intereses, cultura de origen o preferencia. La realidad es que se afianza una reorganización social por diversos intereses y estos rasgos sociales no deberían ser motivo de división o exclusión.

El establecimiento de políticas, planes o programas debe contar con un sentido humanístico, servir de catalizador en pro de la integración de los diversos grupos en una sociedad plural, motivando una integración nacional tanto en lo cultural como en lo social. En la actualidad, las naciones se reorganizan constantemente por la gran movilidad que se ha generado a escala local, regional e internacional, por diversas razones de índole económica, social o política, generando nuevas demandas y servicios.

Para todas las disciplinas, esto se constituye en un reto interesante de abordar, en particular para nuestra disciplina, como facilitador de servicios de información y diseñador de accesos al conocimiento humano. Nuestra profesión demanda una actuación profesional y ética, el desarrollo de habilidades y una capacidad creativa para el establecimiento de reglas claras e incluyentes con un matiz de pluralidad.

Constantemente, tenemos que interactuar con normas que no sólo resalten derechos que tenemos, 
Tolerancia, políticas culturales y sociales, y ...

sino también que mencionen las obligaciones que nos corresponden al ser parte de una sociedad. Hacer conciencia en la población es muy importante para buscar un equilibrio, teniendo la posibilidad de un estado más compartido, incluyente y tolerante.

El nuevo orden social emergente se encuentra en constante crecimiento, y se hace más complejo al adicionarse factores económicos, religiosos, ideológicos, de género, étnicos, laborales, sexuales, etcétera; en conjunto, éstos generan movimientos en la población que demanda más y nuevos servicios, piden espacios acordes a los perfiles de interés de las personas pertenecientes a grupos que tienen la necesidad creciente de una representatividad en el orden social; además, desean sentirse parte del desarrollo social de la nación, tomar decisiones dentro de la sociedad a la cual pertenecen sin perder su identidad de origen.

Para ello, se requiere contar con espacios y con instituciones en manos de profesionistas que, entre otras cosas, apoyen y fomenten accesos a la información y que deseen tener disponible o resguardar el valor cultural del contenido para los grupos que surgen por el multiculturalismo. En cierta forma hay una demanda de sistemas que facilitan la información necesaria para asimilar en los grupos el proceso de integración, de una manera democrática, de la nueva cultura emergente, buscando preservar la 
cultura de origen. Es un verdadero reto en medio del caos; es un monstruo que está en proceso, en aumento y con mutaciones constantes.

Para poder entender la idea del multiculturalismo como un caos, vale la pena meditar sobre lo propuesto por Torres (2001). Dicho autor cita Los rituales del caos, de Carlos Monsiváis, donde se afirma que "El perfeccionamiento del orden empieza en el caos". La reflexión de Monsiváis se puede entender como una invención del orden social, o el inicio de una propuesta para recuperar el orden necesario en la convivencia y en el desarrollo social de los nuevos grupos.

En el mismo sentido, Torres (2001) cita también a Jorge Luis Borges, quien habló de "Las aventuras secretas del orden". Hay coincidencia entre los autores citados en relación con la metáfora que encierran sus palabras, las cuales representan y resumen, en buena parte, el nuevo orden social ante los dilemas del multiculturalismo; es una llamada de atención que, si le damos el valor en tiempo y forma, adecuando soluciones y buscando propuestas a las demandas, podremos adelantarnos evitando la generación de un verdadero estado del caos.

Esta perspectiva del caos (Arizpe, 2006) se acepta como fuente de todas las formas dinámicas y complejas de la vida, y resulta inherente a las diversas situaciones de cambios, aparentemente insignifican- 
Tolerancia, políticas culturales y sociales, y ...

tes, pero que pueden ser detonadoras de grandes transformaciones en la sociedad. Lo planteado tiene el propósito de construir un marco de entendimiento de los cambios culturales en curso, apoyándonos en la necesidad de un conocimiento antropológico y sociológico de la comunicación que se ha generado en las nuevas culturas urbanas.

El proceso cultural tiene una capacidad o dinámica de irse mutando y, al mismo tiempo, adecuando a diferentes situaciones. Claro está, éstas pueden ser caóticas si no se les pone atención y cuidado; empero, el fenómeno bien conducido, bajo planes estratégicos, puede llegar a buen puerto con resultados positivos.

El término multiculturalismo tiene varias formas de definirse, lo que genera distintas acepciones del concepto. Para poder abordar el tema con más elementos que ayuden a ir centrando el desarrollo del presente trabajo, es conveniente revisar algunas acepciones encontradas sobre perspectivas del multiculturalismo en diversos entornos y contextos que se van interrelacionando en la sociedad actual; así tenemos:

- Lo social invita a los distintos grupos culturales a tomar conciencia de la diversidad cultural existente, representada por identidades propias en los distintos ámbitos, tales como grupos religio- 
sos, nacionales y étnicos, con el objetivo de lograr una convivencia positiva y no violenta.

- Lo económico se basa en la "globalización" a un nivel consumista y productivo, con formas de identidad cada vez menos sociales.

- El enfoque epistemológico reconoce al lenguaje y los discursos que transmite cada cultura como la manera en que se nos transmite lo extraño junto a lo diverso de lo extranjero.

- La educación tiene como objetivo una reflexión crítica de todos los elementos, como las creencias, los valores y los prejuicios culturales que permiten las relaciones interculturales.

- La ética-política propone una convivencia ética multicultural, teniendo como fundamento el reconocimiento y la aceptación de las otras culturas, y a la vez renunciando a todo aquello que conlleve al poder y a la dominación.

Vivimos frente a dos fenómenos que modifican paulatinamente la relación en las naciones, en la sociedad y en los seres humanos. Éstos son: la globalización y el multiculturalismo, términos ligados entre sí en un alto porcentaje; por sus relaciones, son prácticamente indisolubles y se han constituido en un proceso constante, en aumento en todas las naciones; además, conllevan una gran movilidad entre las zonas menos favorecidas por el desarrollo hacia las de mayor crecimiento económico. En este 
Tolerancia, políticas culturales y sociales, y ...

fenómeno participan personas de diversas culturas, costumbres, religión, etcétera, por mencionar algunos aspectos.

$\mathrm{Al}$ no atender estas nuevas formas de organización de la sociedad, se ha presentado un problema que se refleja en la falta de oportunidades, acentuado por la desigualdad económica. Los grupos generan y demandan derechos en varios sentidos, entre los que destaca el derecho a la información, que posiblemente sea el más importante.

La información es el insumo primordial en la sociedad moderna por su incidencia en un alto desarrollo económico, social, científico y tecnológico; se constituye en la piedra angular para cualquier nación que desea integrarse a un mundo globalizado; es una demanda de crear accesos a la información cultural, científica y tecnológica, que permita a las naciones y a la sociedad en su conjunto tener la oportunidad de mejorar y elevar estándares de vida, ayudando a ser más competitivos en la generación de conocimiento con productos de calidad que permitan una mayor interacción.

Frente a las demandas sociales emanadas del multiculturalismo se deben enmarcar las políticas públicas en un sentido humanístico y democrático. Como parte de este marco, las bibliotecas pueden ser catalizadoras creando accesos y diseñando servicios de información basados en la aplicación de cri- 
terios bibliotecológicos y apoyados en el uso de nuevas tecnologías.

Desde el punto de vista bibliotecológico, se tienen que estructurar e implementar servicios de información, como lo menciona De Gennaro (1993), usando la tecnología en cada uno de los procesos para organizar la información disponible y el conocimiento que se genera, incidiendo en el desarrollo local y regional con la integración social y presencia internacional, coadyuvando a una sociedad más democrática en términos de equidad e igualdad entre los grupos existentes.

Será importante la integración de los grupos de inmigrantes en las actividades socioeconómicas y culturales en una nación; no es cosa fácil, pues se dificulta por la falta de oportunidades para trabajar o integrarse al desarrollo. Al surgimiento constante de nuevos actores sociales, pocos son los favorecidos en una sociedad multicultural por su reconocimiento o participación, o por su poder económico; todo como resultado de la falta de medidas democráticas.

El fenómeno migratorio es a escala mundial, se trata de una característica del momento histórico que está viviendo la humanidad, pues no hay sociedad o grupo social ajeno a la llegada de personas con diversas costumbres, cultura o idioma. Se han establecido iniciativas para atender el fenómeno del multiculturalismo a través de políticas o medi- 
Tolerancia, políticas culturales y sociales, y ...

das democráticas que ayuden a un mejor entendimiento e integración de los individuos al nuevo orden social que se presenta.

Las políticas deben ser una alternativa que permita garantizar a las personas o grupos preservar su identidad cultural, al mismo tiempo que se otorgue una forma de motivación sutil que sirva para integrarlos a la sociedad que los acoge, preservando sus garantías de grupo y respetando sus derechos e intereses. Todos, al ser parte de una nación, tendremos al mismo tiempo el compromiso de asimilar, acatar y respetar ciertas obligaciones.

México tiene que buscar equilibrios en este nuevo tipo de relaciones al establecer una participación responsable; tiene que adoptar una sensibilidad humana y exigir de los participantes una actuación ética sin perder de vista el sentido social y humanístico de las políticas para un entorno social y cultural plural. La finalidad, justamente, es buscar equilibrios en un marco normativo en el que todos estén incluidos en la instrumentación de políticas para no caer, por descuido u obviedad, en algún tipo de exclusión, motivando fricciones o el caos social.

Álvarez (2004) menciona que en México: "La cultura política construida se arraigó en ciertos estilos y lenguajes de la acción política dominante que deriva de la condición subordinada de la acción política y social del Estado, se sustentó en principios 
como el autoritarismo, el poder personalizado, la antidemocracia y la exclusión[...]”. Ésa fue, por décadas, la forma de hacer política en México.

A partir de 1968 se generaron cambios en las estructuras de gobierno y en la sociedad mexicana. En la siguiente década se permitió e inició cierta apertura e hicieron su aparición nuevos actores. Comenzó una relación áspera y burda entre gobierno y sociedad. La nueva relación demandó una nueva estructura, lo que nos llevó a (Mora, 1997) realizar reformas jurídicas, institucionales y administrativas para forjar una renovada integración política con participación de nuevas fuerzas por el reacomodo de algunos grupos sociales.

En la actualidad, el desafío consiste en construir instituciones de gobierno democráticas basadas en nuevas formas de representación legítima de los individuos, capaces de desempeñar con responsabilidad las tareas de gobierno, por ejemplo, la administración de educación, salud, accesos y transparencia de la información, con la aplicación de nuevas tecnologías, logrando una integración en el ámbito local, regional, nacional e internacional. Todo esto demanda comunicación y cooperación, una actuación responsable de todos, independientemente de ideologías. 
Tolerancia, políticas culturales y sociales, y ...

En cuanto al derecho a la información, Alvarado (1997) menciona que en México se han suscitado importantes cambios; si bien el país no se ha democratizado, se tiene mayor demanda de información, se ha ganado una mayor libertad de expresión. La información es un actor político que ha construido espacios de diálogo y de opinión para todos los sectores sociales; los procesos de cambio son irreversibles con la difusión y el acceso a la información como parte de un proceso social, político y de desarrollo.

Borea (1997) plantea que la democracia no puede vivir con instrumentos de antaño en la época en que las comunicaciones, la ciencia, el pensamiento, en suma, todo ha evolucionado. Si no se acepta empatar los términos de democracia, eficacia y calidad, algunas regiones se pueden ver comprometidas ante otras formas en la toma de decisiones con gobiernos tradicionales.

La demanda de que la democracia pase de ser una esperanza a un proceso social, requiere del compromiso profesional y experiencia de todas las disciplinas con una actuación ética, para avanzar más allá de lo que dicen los textos con hipótesis o proyectos llenos de buenos propósitos en materia de política.

Es evidente que la información es un asunto clave a favor de la democratización; por ello, se ha planteado que uno de los componentes centrales en las democracias modernas radica precisamente en ese punto de 
disponibilidad y acceso a la información. En tales sociedades, los ciudadanos tienen derecho a buscar fuentes alternativas de información; incluso hay fuentes alternativas de información que están protegidas por la ley para garantizar su acceso y uso de manera permanente. Gutiérrez (2005) asegura que una forma de hacer cumplir lo descrito arriba es cuando se demuestra que el derecho a la información depende, en gran medida, de la rendición de cuentas del Estado a la sociedad periódica y claramente.

No se trata de una apertura indiscriminada a la información que manejan las diversas instancias de la autoridad; se tienen que precisar los ámbitos y asuntos en que, por su naturaleza, deban mantenerse con reserva, a riesgo de afectar la seguridad nacional, la seguridad pública o la privacidad de las personas; por ejemplo, nuevamente Gutiérrez (2005) se refiere a las declaraciones internacionales de derechos humanos que reconocen explícitamente la relación que existe entre libertad de expresión entendida como una forma de participación y el derecho a la información.

Hasta aquí podemos decir que la libertad de expresión y el acceso a la información son medulares en la construcción de un "criterio público" (Yankelovich, 1995), capaz de fortalecer el desarrollo de una relación más democrática entre los miembros de la sociedad, instituciones públicas, procesos polí- 
Tolerancia, políticas culturales y sociales, y ...

ticos y sociales, ante la carencia de parámetros claros que orienten la acción de las instituciones de cara a un tejido social marcado contradictoriamente, por desigualdades y rezagos culturales por la emergencia del pluralismo que progresivamente ha ido reconfigurando las condiciones legales e institucionales de la interacción y la competencia política.

Podemos señalar que el pluralismo constituye un ingrediente fundamental en la democracia, pues da la posibilidad a los individuos de escoger e integrarse a un grupo o asociación de manera voluntaria, como a los de carácter político, o algunos civiles en los cuales se persigue una diversidad de finalidades. Según González (1999), independientemente de sus objetivos, si son agrupaciones verdaderamente democráticas, pueden contribuir a dar densidad al tejido social, fundamental para una democracia vigorosa y capaz de apertura a las nuevas demandas; capaz también de una renovación constante, además una sociedad civil con presencia y participación ciudadana con diferentes intereses, pues aparecen nuevos actores sociales distintos al gobierno que demandan la urgente construcción de políticas sociales.

En este sentido, Penso (2001) dice que un "buen gobierno" es el resultado del despliegue de una serie de capacidades técnicas y administrativas que se traducen en políticas específicas para el bienestar de la 
ciudadanía; además, una participación de los actores sociales, civiles, privados y gubernamentales es la finalidad de una intervención efectiva en la estructura de políticas públicas conjugadas con una gestión social, para proporcionar "condiciones de solidaridad y autosustentación para promover la equidad social”.

La carencia de sensibilidad a las demandas sociales nos presenta, por ejemplo, generación de violencia en los jóvenes y aparición de disturbios urbanos que dejan al descubierto una ira destructora, que marcan distancias en un sistema político por la carencia de instituciones que den respuesta a sus demandas y a sus necesidades sociales, culturales (entre las que se encuentra incluso la información).

La interacción entre lo global, lo regional, lo nacional o lo local nos exige técnicas de comunicación, información y acceso al conocimiento basadas en nuevas tecnologías, factores que nos obligan a diferenciar y a tener presentes los nuevos códigos culturales que se desarrollan; tenemos que estar concientes de que el concepto de cultura se modifica y aumenta en las nuevas condiciones del sistema global. A través de las nuevas tecnologías (Arizpe, 2006) se contribuye a crear nuevas posibilidades para la codificación de palabras, imágenes y mensajes múltiples, dando origen a un desarrollo de ciberculturas. 
Tolerancia, políticas culturales y sociales, y ...

El nuevo reagrupamiento de la sociedad civil genera la búsqueda de una participación política con nuevos valores que se alientan y fortalecen con la globalización, fenómeno que hace emerger otros universos de identidades que derivan en una sociedad red o en una sociedad de redes. Todo esto ha hecho que tengamos un choque cultural, de intereses y de géneros. Existe una frontera que no debe de obviarse ni olvidar, sino más bien franquear en pro del reconocimiento del otro; tenemos que defender nuestra memoria, nuestro medio ambiente, nuestra diversidad cultural y hasta nuestras especies, buscando un equilibrio en la relación, generado por un ambiente de respeto y libertad.

La exclusión hace que se pierda la dinámica y el valor general de las normas e instituciones, haciendo vulnerables los requerimientos presentes y futuros de una sociedad que pretende organizarse bajo principios de una democracia justa y participativa. Podría decir que la socialización de la información se perfila, de esta manera, como una premisa indispensable para el armado de un sistema más democrático, basado en la accesibilidad, disponibilidad y cobertura, usando las nuevas tecnologías para acentuar su valor, calidad, legitimidad social y oportunidad de la información.

Y como estímulo, según Gutiérrez (2005) es necesaria la construcción de identidades sociales asenta- 
das en el aprecio de la tolerancia, el respeto a la legalidad y la corresponsabilidad, fomentando la participación ciudadana informada, para lograr el rechazo a la discriminación y a la violación de los derechos humanos. Los puntos mencionados son indispensables para un proceso cultural, articulando una relación entre sociedad e instituciones de forma equilibrada y con responsabilidad de ambas partes.

Disciplina bibliotecológica, bibliotecas y disponibilidad de la información, constituyen un eslabón primordial en la estructuración de servicios para el establecimiento de políticas sociales y culturales en las instituciones públicas, en donde los usuarios acudan y demanden servicios por un interés personal o de grupo. Vale la pena hacer una reflexión con relación a que la información que se demanda para los usuarios (nuevos ciudadanos) es resultado del multiculturalismo. Debemos pensar que la información no es un elemento accesorio en la construcción de una nueva ciudadanía; por el contrario, constituye un catalizador al dar bases sociales para el funcionamiento e integración al desarrollo global de la sociedad y de las instituciones nacionales, con una profesionalización de la tarea bibliotecaria.

Crear accesos y compilar la información necesaria será una tarea ardua, de gestión con la información que se ha convertido en el insumo y el corazón de las 
Tolerancia, políticas culturales y sociales, y ...

interacciones sociales y políticas, así como económicas; además, debemos ser capaces de dirigir su sentido, tener la capacidad de medir y potencializar sus alcances para que la sociedad se desarrolle y pueda vivir en armonía consigo misma y con su entorno.

Si un sistema, desde el punto de vista social, niega el acceso a la información, el usuario lo convertirá en solamente un receptor de beneficios; no tendrá capacidad para generar cambios ni iniciativa en el desarrollo de una sociedad más democrática; empero, por el contrario, sí puede convertirse en un riesgo enorme para la estabilidad social y nacional, dependiendo de su capacidad de interacción y de organización con grupos afines o de interés específico, pues buscará ser escuchado y tomado en cuenta por la sociedad.

El nuevo orden en la sociedad lleva a una renovada naturaleza del pacto democrático, en el que se presentan nuevas coordenadas culturales, jurídicas e institucionales que redefinen el tipo de convivencia social, con enfoque en la pluralidad social, cultural y política. Sartori (1987) nos dice que, por lo tanto, es necesario encontrar puntos de acuerdo sobre cómo resolver las diferencias, proteger las libertades y los derechos de todos, así como asegurar la reproducción estable de la comunidad.

Se tiene que pensar en una responsabilidad, gestión y conducción política basadas en equilibrios y 
controles propios de un Estado democrático de derecho, en el que se garanticen la libertad de expresión, así como el acceso a la información pública, recordando siempre un principio elemental: abatir la excepcionalidad de grupos. El multiculturalismo engloba tres elementos: democracia, globalización y pluralidad, que llaman nuestra atención en atender y entender los asuntos ligados al reconocimiento político de la diversidad, que han permeado paulatinamente a las estructuras institucionales y sociales de índole público. Por su gran movilidad y expansión, el multiculturalismo se alimenta del nuevo orden; por ejemplo, el crecimiento de los estados-nación (más de 200 en la actualidad) y la expansión de las minorías territoriales presentan una nueva dinámica a nivel local y global.

Para cumplir con los derechos y como resultado de discusiones en el ámbito internacional sobre temas culturales, la ONU, por medio de la UNESCO, instrumentó la Comisión Mundial de Cultura y Desarrollo que se ha avocado al problema con la finalidad de tener un mejor entendimiento de la diversidad cultural en América Latina, así como en el resto del mundo. Organismos que derivan en un nuevo orden reflejan un mundo cambiante y en construcción permanente, en el que hay el deber de considerar y orientar al mayor número de esfuer- 
Tolerancia, políticas culturales y sociales, y ...

zos a favor del pluralismo, en un marco de tolerancia, entendimiento y comprensión del fenómeno.

La profesión y las bibliotecas están inmersas en el desarrollo de la sociedad con el deber de conocer la problemática que se presenta en el nuevo orden social y político; por ello la importancia de su participación en el diagnóstico, diseño, difusión y aplicación de las políticas sociales, culturales y educativas. La tolerancia y la responsabilidad serán base del conocimiento en la disciplina de los bibliotecarios profesionales involucrados con la docencia que, desde el punto de vista de Freire (1997) presenta una serie de principios éticos para enseñar. Según él, es el principio de un proyecto de ciudadanía multicultural, es una forma de liberalismo, es un decálogo que presenta las virtudes de un maestro al enseñar. El bibliotecario en su ejercicio profesional, de manera implícita, se constituye en un docente al interactuar como intermediario o facilitador de información para los usuarios. Freire señala que:

1. Requiere respeto por los conocimientos del estudiante.

2. Requiere estética y ética.

3. Poner el ejemplo.

4. Respeto a la autonomía del estudiante.

5. Buen Juicio.

6. Curiosidad. 
Diversidad cultural y acceso a la información

7. Confianza en uno mismo, capacidad profesional y generosidad.

8. Libertad y autoridad.

9. Saber escuchar.

10. Amar a los estudiantes.

Los maestros, como parte del proceso formativo de nuevas generaciones -al considerar o al hacer suyos parte de algunos de los puntos anteriores y aplicarlos de manera constante y metódica, para que de una manera sistemática los transmita a sus alumnos-, podrían ser el inicio de una nueva generación basada en la tolerancia y en el entendimiento de las necesidades de los demás.

El planteamiento anterior es importante dentro de nuestra disciplina, por la relevancia que juegan las bibliotecas en el proceso de integración social y como uno de los eslabones claves para el nuevo orden de grupos en la sociedad que están en continua evolución $y$, consecuentemente, presentando nuevos paradigmas.

El trabajo y la creatividad dentro de las bibliotecas pueden tener incidencia positiva en el desarrollo e integración de los nuevos grupos sociales que surgen constantemente, que además presentan y tienen derechos que deben hacerse valer.

El trabajo bibliotecario tiene y puede generar un gran valor agregado en el sentido de que, si se realiza de una manera ética y profesional, de acuerdo a 
Tolerancia, políticas culturales y sociales, y ...

las necesidades de los nuevos grupos sociales con relación a sus demandas de servicios de información, puede contribuir a la consolidación de una verdadera democracia social con el acceso a la información. Se tiene que lograr una participación permanente, en aumento y activa, del gremio bibliotecario en los diversos foros de la sociedad, sean de índole académico o político, para tener derecho a voz y voto, con base en los intereses que mueven a nuestra sociedad en materia de información, actividad que constituye un desafío profesional.

Actividad irrenunciable por la responsabilidad que tienen las bibliotecas por ser depositarias del conocimiento y de la memoria colectiva, éstas son el acceso y las facilitadoras en la relación social y en la construcción de una democracia a través de los servicios de información frente a las demandas de información que se presentan con el surgimiento de nuevos grupos resultado del multiculturalismo. No existe posibilidad de una ciudadanía multicultural sin una capacidad de diálogo que implica que tenemos que educar para la democracia el mutuo reconocimiento de los individuos, en donde todos aprendan y comprendan la importancia de la riqueza de la diversidad cultural en la sociedad como una acción afirmativa. 
Diversidad cultural y acceso a la información

Sin una teoría firme y objetiva que sea atractiva social y políticamente, el pueblo perecerá; Friedrich Nietzsche dijo al respecto: "No conozco mejor aspiración en la Vida que la de perecer en la persecución de lo grande y lo imposible". Sociedad e instituciones, biblioteca y bibliotecarios profesionales, hemos recibido el llamado a participar en una democracia multicultural, en búsqueda de lo grande y lo imposible, aun a riesgo de perecer ante el caos.

\section{ANEXO}

\section{Declaración de Glasgow por la IFLA ${ }^{1}$}

Vale la pena hacer referencia a la "Declaración de Glasgow sobre las bibliotecas y los servicios de Información y la Libertad Intelectual" de la Federación Internacional de Asociaciones de Bibliotecarios y Bibliotecas (IFLA) en el 75 aniversario de su creación, en Glasgow:

1 Declaración, preparada por IFLA/FAIFE. Aprobada por la Junta de Gobierno de la IFLA (28 de marzo del 2002) en La Haya, Los Países Bajos. Proclamada por el Consejo de la IFLA el 19 de agosto del 2002 en Glasgow, Escocia. 
Tolerancia, políticas culturales y sociales, y ...

La IFLA proclama el derecho fundamental de los seres humanos a acceder y expresar la información sin ningún tipo de restricción.

Con el apoyo de sus socios repartidos por todo el mundo, defiende y promueve la libertad intelectual como se expresa en la Declaración Universal de los Derechos Humanos de las Naciones Unidas. Esta libertad intelectual abarca la riqueza del conocimiento humano, la diversidad de opinión, el pensamiento creativo y la actividad intelectual.

Afirma que la dedicación a la libertad intelectual es una responsabilidad fundamental de los bibliotecarios y documentalistas de todo el mundo, expresada a través de códigos de conducta ética y demostrada mediante la práctica.

La IFLA afirma que:

Las bibliotecas y los servicios de información ofrecen acceso a la información, ideas y productos de la imaginación en cualquier soporte y sin importar las fronteras. Actúan como intermediarios del conocimiento, pensamiento y cultura, ofreciendo ayuda esencial para la toma independiente de decisiones, el desarrollo cultural, la investigación y el aprendizaje continuo de individuos y grupos.

Las bibliotecas y los servicios de información contribuyen al desarrollo y mantenimiento de la libertad intelectual y ayudan a salvaguardar los valores democráticos y los derechos civiles universales. 
En consecuencia, están comprometidos a ofrecer a sus usuarios acceso sin restricción a recursos y servicios relevantes y a oponerse a cualquier forma de censura.

Las bibliotecas y los servicios de información deberán adquirir, preservar y hacer accesibles la mayor variedad de documentos posible, que reflejen la pluralidad y diversidad de la sociedad. La selección y disponibilidad de los materiales y servicios bibliotecarios deberá regirse por consideraciones profesionales y no por puntos de vista políticos, morales y religiosos.

Las bibliotecas y los servicios de información deberán poner a disposición de todos los usuarios por igual sus materiales, instalaciones y servicios. No deberán discriminar por ninguna razón como por la raza, origen nacional o étnico, género o preferencia sexual, edad, discapacidad, religión o ideología.

Las bibliotecas y los servicios de información deberán proteger los derechos de cada usuario a la privacidad y confidencialidad de la información que buscan o reciben y los recursos que han consultado, sacado en préstamo, adquirido o transmitido.

Por lo tanto, la IFLA insta a las bibliotecas, a los servicios de información y a su personal a que defiendan $\mathrm{y}$ fomenten los principios de la libertad intelectual y ofrezcan acceso sin restricciones a la información. 
Tolerancia, políticas culturales y sociales, y ...

\section{Bibliografía}

Álvarez Enríquez, Lucía. La sociedad civil en la ciudad de México: actores sociales, oportunidades politicas y esfera pública. México, UNAM/CEIICH, Plaza y Valdés, 2004. $270 \mathrm{p}$.

Arizpe, Lourdes (coord.). Retos culturales de México frente a la globalización. México, $\mathrm{H}$. Cámara de Diputados, LIX Legislatura - Edit. Porrúa, 2006. 627 p.

De Gennaro, Richard. Bibliotecas: la tecnología y el mercado de la información. México, Iberoamericana, 1993. $335 \mathrm{p}$.

Freire, Paulo. Pedagogía da autonomía: saberes necesarios à práctica educativa. Sao Paulo, Paz e Terra, 1997. 165p. (6ta. ed)

González Souza, Luis (coord.). Un Futuro para México: visiones y propuestas desde la sociedad. México, Causa Ciudadana, Agrupación Política Nacional, 1999. 175 p.

Guerrero López, Roberto. Información y democracia: los medios de comunicación social y su influencia sobre la política. El caso de México. México, UAM-Azcapotzalco -Ed. Pomares, 2005. 239 p.

Gutiérrez Martínez, Daniel (comp.). Multiculturalismo: desafíos y perspectivas. México, Siglo XXI, 2006. 328 p.

Mora y Araujo, Manuel (comp.). Los actores sociales y políticos en el proceso de transformación en América Latina. Buenos Aires, Honrad Adenauer, 1997. 367 p. 
Diversidad cultural y acceso a la información

Penso D’Albenzio, Cristina T. y Isabel Font Playán (Coord.). Políticas sociales y nuevos actores. México, UAM-Azcapotzalco, 2001. 223 p.

Primer encuentro Internacional sobre filosofía de la cultura y multiculturalismo. Campeche 2001 (memoria). Campeche, Camp. México, CONACUlTA-INAH, 2004. 394 p.

Sartori, Giovanni. Partidos y sistemas de partidos. México, Alianza Editorial, 1988. 2 v.

Torres, Carlos Alberto. Democracia educación y multiculturalismo: dilemas de la ciudadanía en un mundo global. México, Siglo XXI, 2001. 363 p.

Yankelovich, Daniel. Para alcanzar un criterio público, como lograr que la democracia funcione en un mundo complejo. México, Publigrafics, 1995. $326 \mathrm{p}$. 


\title{
Diversidad cultural y bibliotecas públicas
}

\author{
ROSA MARÍA MARTÍNEZ RIDER \\ La misión del bibliotecario nace de la nece- \\ sidad social a la que sirve la profesión \\ José Ortega y Gasset
}

\section{Introducción}

\begin{abstract}
Se presentan algunos conceptos sobre cultura, Smulticulturalismo y diversidad cultural, así como la reflexión sobre la responsabilidad social de la biblioteca pública para atender a las comunidades indígenas y las de inmigrantes. Por último, se presenta un estudio exploratorio en 10 bibliotecas públicas de la ciudad de San Luis Potosí con relación a la atención de tales comunidades.
\end{abstract}

\section{La diversidad cultural y las bibliotecas públicas}

Una de las características de la posmodernidad es el multiculturalismo, que surge como un concepto derivado de las transformaciones sociales. Por 
ejemplo, siempre ha habido migración en el mundo, es una acción cotidiana en el ser humano, cuando trata de alcanzar nuevas expectativas individuales, familiares o grupales, y hoy se reflexiona desde nuevas perspectivas y enfoques.

Respecto al concepto de cultura, Stavenhagen plantea que ésta es la "[...]totalidad de prácticas, significados y relaciones sociales que definen a determinado tipo de colectividades humanas y las distinguen de otras"; ${ }^{1}$ esta definición es la que invita a la inclusión, a valorar a todos los grupos étnicos y a las minorías de una sociedad.

La Declaración universal de la UNESCO sobre la diversidad cultural propone que la cultura es "El conjunto de los rasgos distintivos espirituales y materiales, intelectuales y afectivos que caracterizan a una sociedad o a un grupo social y que abarca, además de las artes y las letras, los modos de vida, las maneras de vivir juntos, los sistemas de valores y las creencias"; ${ }^{2}$ esta perspectiva destaca la construc-

1 R. Stavenhagen, "Educación y derechos culturales: un desafío", http://catedradh.unesco.unam.mx/Puebla2002extRStavenhag en.htm

2 "Declaración Universal de la UNESCO sobre la diversidad cultural", http://www.unesco.org/culture/pluralism/diversity/htm/ $\mathrm{sp} /$ indexsp/shtlm (fecha de actualización, 25 de enero del 2002). 
Diversidad cultural y bibliotecas públicas

ción de un sujeto con circunstancias concretas (una identidad, una etnia, un sistema axiológico y de creencias, etc.) que se ubica en otro contexto, con circunstancias diferentes.

Siguiendo las ideas anteriores, Requejo y Zapata indican que el multiculturalismo "[...]describe el hecho de la coexistencia de una pluralidad de culturas bajo un mismo marco político" ${ }^{3}$ que debe darse de forma integral, resolviendo los conflictos que se susciten con apertura, comprensión y diálogo. Pérez sostiene que debe basarse en "[...]el respeto a las diferencias personales, grupales o culturales, lleva a [...] la afirmación de la tolerancia, a la aceptación del otro, a la yuxtaposición cultural". ${ }^{4}$ Así, el nacionalismo pluralista, contra el de tipo organicista o culturalista, propone "atender y proteger los contextos culturales de los ciudadanos, como ámbitos proveedores de sentido, al tiempo que, en lugar de considerarlos como algo dado y saturado en la historia y la tradición, los entienden normativamente como un ámbito más del ejercicio de la política

3 F. Requejo, y Zapata-Barrero, R. "Multiculturalidad y democracia", en: Mellón, J. A. Las ideas políticas en el Siglo XXI. Barcelona, Ariel, 2002, p. 92.

4 A. I. Pérez Gómez, La cultura escolar en la sociedad neoliberal. $3^{\text {a }}$. ed. Madrid, Morata, 2000, p. 26. 
democrática", ${ }^{5}$ con significados de inclusión, donde las bibliotecas deben promover, apoyar y fortalecer la diversidad cultural.

El multiculturalismo es complejo, pluridimensional (porque es parte de la política, la economía, la sociedad, etc.) y requiere de un replanteamiento en los esquemas democráticos para alcanzar la igualdad desde las diferencias, pero se hace hincapié en que "diferencias no equivale a discriminar y [...] diversidad no equivale a desigualdad." fiere a aceptar al otro, con distintas costumbres, religiones o historia, en un marco simétrico, es decir, desde la igualdad política de los derechos sociales y culturales, porque "en la comparación es donde mejor se puede construir el respeto y el reconocimiento de la realidad multicultural"7 y evitar así los conflictos y las tensiones que derivan en violencia o fundamentalismos.

Requejo y Zapata ${ }^{8}$ distinguen cuatro tipos:

5 R. Máiz, “Las ideologías nacionalistas contemporáneas: funcionalidad, estructura y tipología”, en: Mellón, J. A., Las ideas politicas en el Siglo XXI, Barcelona, Ariel, 2002, p. 141.

6 J. García Castaño, Pulido Moyano, R. A. y Montes del Castillo, A. "La educación multicultural", Revista Iberoamericana de Educación (13), 1997.

7 Ibíd.

8 F. Requejo y Zapata-Barrero, R. "Multiculturalidad y democracia”, Op. cit., pp. 92-93. 
Diversidad cultural y bibliotecas públicas

1. El relacionado con temas particulares (derechos humanos, feminismo)

2. La inmigración

3. El pluralismo nacional

4. El indigenismo

Sin embargo, destacan que mientras el multiculturalismo sólo es una yuxtaposición, la interculturalidad es "[...] un valor político y social que se debe proteger"; es una parte importante de los derechos culturales que abarcan la información y la educación, pues "[...] en los últimos años, se ha puesto cada vez más el acento en [...] las minorías como los pueblos autóctonos y en el correspondiente derecho personal a identificarse o no con una comunidad". ${ }^{9}$ La biblioteca pública permite el acceso al conocimiento local, las tradiciones y, en síntesis, a la cultura que se plasma en el patrimonio; debe contribuir a evitar la discriminación, el rechazo y la exclusión, proporcionando información dirigida a atenuar estas situaciones negativas, ya que tiene la importante función de la cohesión social.

En México hay comunidades indígenas y de inmigrantes que provienen de diversos países. Los indígenas pueden ser simultáneamente migrantes, $\mathrm{y}$ ambos solicitan respeto a su cultura, su libertad, sus

9 "La problemática de la diversidad cultural", http:// prodiversitas.bioetica.org/nota52htm 
derechos y a la conservación de su identidad. En América Latina, "[...]los pueblos indígenas [...] enfrentan $[. .$.$] carencias, olvidos [...] y presiones socia-$ les. Culturas únicas se ven así sometidas a situaciones de pobreza, enfermedad, analfabetismo y pérdida de la identidad"; ${ }^{10}$ por ello, hay que fomentar el ejercicio de sus derechos, como el de la educación, establecido en el Artículo $3^{\circ}$ constitucional; el derecho a la información, a su vez, está promulgado en los artículos $6^{\circ}$ y $7^{\circ}$, en los cuales se enmarca la biblioteca, específicamente la pública que, de acuerdo al Manifiesto de la UNESCO, ${ }^{11}$ “[...] es un centro local de información que facilita a sus usuarios todas las clases de conocimiento e información"; se destaca que los servicios se brindan sobre la base de igualdad de acceso para "minorías lingüísticas" a personas que "[...]por una u otra razón no pueden hacer uso de los servicios y materiales ordinarios".

La biblioteca pública garantiza la libertad en un régimen democrático, pues entre sus objetivos está la protección de los derechos humanos y al patri-

10 E. Civallero, "Bibliotecas aborígenes", http://www.sagpya. mencon,gov,ar/new/0-0/forestacion/biblos/aborigenes.pdf. search = 'Edgardo\%20Civallero\%20 bibliotecas $\% 20$ aborigenes

11 "Manifiesto de la UNESCO sobre la Biblioteca Pública" http:// www.ifla.org/VII/s8/unesco/span.htm (última revisión, septiembre del 2004). 
monio cultural de las minorías, así como fomentar el derecho de autor y el depósito legal de las obras culturales de estos grupos sociales. Es un hecho que nunca desaparecerán las barreras ideológicas, por lo que el camino es consensuar y acordar; en el peor de los escenarios, tolerar, tratando de cerrar brechas económicas, políticas o tecnológicas.

En la dimensión educativa, las escuelas de Bibliotecología deben considerar tres aspectos:

1. Integración del currículum con el aprendizaje basado en problemas, proyectos y estudios de casos, tomando como eje central a la diversidad cultural.

2. El desarrollo de las competencias sociales y culturales especiíficas para atender a las minorías en las bibliotecas, mediante el conocimiento de sus contextos y formas de relación social.

3. El desarrollo de competencias lingüísticas, pues, para atender y dialogar, hay que comprender el vocabulario del emisor, el lenguaje gestual, el oral y/o escrito.

De acuerdo a los cambios en la educación, los planes de estudio deben organizarse sobre la base de la flexibilidad institucional, académica, curricular y pedagógica, para brindar al egresado mayores oportunidades de desarrollo con prácticas profesionales diversificadas y, además, que éstos propongan 
a las instituciones sociales proyectos de desarrollo en temas cruciales como la diversidad cultural.

De lo antes expuesto, para atender a las minorías, las bibliotecas públicas deben considerar lo siguiente:

\begin{tabular}{|l||}
\hline \multicolumn{1}{|c||}{ COMUNIDADES INDíGENAS } \\
\hline Colección bilingüe para apoyar la educación y la información. \\
\hline $\begin{array}{l}\text { Fomentar la alfabetización y establecer programas de hábito de } \\
\text { lectura. }\end{array}$ \\
\hline $\begin{array}{l}\text { Bibliotecario con competencias sociales y culturales especiales (do- } \\
\text { minar las habilidades de las lenguas indigenas, conocimiento y res- } \\
\text { peto de las costumbres, etc.) }\end{array}$ \\
\hline $\begin{array}{l}\text { Actividades de integración entre las culturas mayoritarias y las } \\
\text { minoritarias. }\end{array}$ \\
\hline Actividades culturales para las comunidades. \\
\hline $\begin{array}{l}\text { Derecho a la información sin censurar la raza, creencias, posturas o } \\
\text { tendencias de los usuarios. Recuperar la tradición oral. Derechos de } \\
\text { autor y depósito legal para las obras creadas por las comunidades in- } \\
\text { dígenas. }\end{array}$ \\
\hline Atender comunidades indígenas ubicadas en zonas lejanas. \\
\hline Trabajo en equipos interdisciplinarios. \\
\hline Protección del patrimonio documental y cultural. \\
\hline \multicolumn{1}{c|}{ ComUnIDADES DE INMIGRANTES } \\
\hline Colección bilingüe para la información y apoyo a la educación. \\
\hline $\begin{array}{l}\text { Bibliotecario con competencias sociales y culturales especiales (do- } \\
\text { minar las habilidades de las lenguas indígenas, conocimiento las cos- } \\
\text { tumbres, etc.) }\end{array}$ \\
\hline
\end{tabular}


Diversidad cultural y bibliotecas públicas

Actividades de integración entre las culturas mayoritarias y minoritarias.

Actividades culturales para las comunidades.

Derecho a la información sin censurar la raza, creencias, posturas 0 tendencias de los usuarios. Derechos de autor y depósito legal para las obras creadas por las comunidades de inmigrantes.

Trabajo en equipo con otros especialistas que tengan conocimiento de los países de origen de los inmigrantes.

\section{Las bibliotecas públicas y la diversidad cultural}

Para conocer cómo atienden 10 bibliotecas públicas de la ciudad de San Luis Potosí (Anexo 1) a las comunidades indígenas y de inmigrantes, se realizó un estudio exploratorio a través de un cuestionario (Anexo 2) y, así, se pudo determinar si éstas tienen las condiciones para satisfacer las necesidades de información de estas comunidades. Los resultados (Anexo 3) se presentan a continuación:

1. Aunque $100 \%$ de las bibliotecas encuestadas afirma que dentro de su misión se incluye la diversidad cultural, sólo 10\% transcribe la redacción en términos concretos de la diversidad cultural. $90 \%$ restante sólo indica que se debe atender a todo tipo de usuario.

2. Aunque la pregunta se refiere a colecciones, $50 \%$ indica contar con algunos materiales para atender las necesidades de información de los indígenas. 
Diversidad cultural y acceso a la información

De este porcentaje, $10 \%$ tiene únicamente algunos diccionarios bilingües, $30 \%$ obras en náhuatl, $10 \%$ en pame y $10 \%$ en tenek. $90 \%$ no indicó las características de estos materiales y 10\% afirma que brinda el servicio con estantería abierta, además de libros, hay videos, casetes o manuales de aprendizaje.

3. 10\% tiene material bilingüe para apoyar la educación de niños y jóvenes indígenas, con estantería abierta y material interactivo; $90 \%$ no cuenta con materiales de este tipo.

4. Con relación a los inmigrantes, $70 \%$ cuenta con material de apoyo en inglés, $10 \%$ en inglés y francés, y $20 \%$ no tiene materiales en lenguas extranjeras.

5. $10 \%$ de las bibliotecas atiende los servicios con licenciados en Bibliotecología, 90\% con personal que tiene otros estudios.

6. 100\% no respondió cuál es el perfil del bibliotecario.

7. $40 \%$ afirma que nunca asisten usuarios de comunidades indígenas. De los servicios que solicitan frecuentemente las comunidades indígenas, $10 \%$ requiere material en español, $10 \%$ consulta la Constitución Política de México, 10\% consulta literatura o datos biográficos, $10 \%$ solicita el préstamo a domicilio y la consulta, $20 \%$ consulta general. 
8. De los servicios que solicitan los usuarios de las comunidades de inmigrantes, $20 \%$ utiliza el préstamo interno y la consulta (Ley Federal del Trabajo y la Constitución Mexicana), 20\% solicita visitas guiadas y consulta, $10 \%$ el periódico, $10 \%$ fotocopias y en $40 \%$ de las bibliotecas no tienen usuarios extranjeros.

9. Respecto a las actividades culturales para apoyar a las comunidades indígenas, $10 \%$ realiza promoción de la lectura, talleres de literatura o concursos literarios y $90 \%$ no organiza ninguna actividad por falta de presupuesto.

10. $100 \%$ no tiene ninguna actividad para inmigrantes.

El principal problema de las bibliotecas públicas encuestadas es el financiero, además de la infraestructura y colecciones vastas, para atender a estos usuarios, como los de zonas alejadas de los grandes municipios. No hay recursos para pensar en la conservación del patrimonio documental. A excepción de una biblioteca, el personal no es bibliotecario profesional y no cubre las características para un servicio especializado. Aunque algunas bibliotecas albergan material en inglés o francés, en la ciudad hay extranjeros que tienen otras lenguas o costumbres como italianos, rusos, austriacos, etc., por lo que es recomendable que se apoye a estas bibliotecas. 


\section{Conclusiones}

1. Las comunidades indígenas y de inmigrantes son parte de la multiculturalidad por lo que es necesario que las bibliotecas públicas tengan la capacidad suficiente para acercar a los usuarios y atender sus necesidades de información.

2. Se requieren profesionales de la información con competencias especiales para buscar los medios de integración de estas comunidades, apoyados por especialistas en otros campos para proporcionar mejores y mayores servicios.

3. Las bibliotecas públicas en San Luis Potosí requieren de infraestructura, colecciones, mayor capacidad de cómputo y conectividad, así como recursos para atender a las minorías culturales y extender sus servicios de atención.

4. Las bibliotecas deben asociarse con otras instituciones públicas y organizaciones no gubernamentales para la creación de redes de atención, cooperación y disposición de recursos compartidos. 


\section{Anexo 1 \\ Bibliotecas públicas encuestadas}

1. Biblioteca Central del estado

Jardín Guerrero 5 (San Francisco)

Tel: 812-85-12

2. Javier Rivera

Av. Universidad (Inst. Potosino de Bellas Artes)

3. Nereo Rodríguez Barragán

Alameda

4. Casa del Poeta Ramón López Velarde

Vallejo \#300

5. Ejército Militar

Ontañon y Av. Juárez.

6. Sor Juana Inés de la Cruz

Plan de Ayutla \#123, Fracc. Saucito

Tel: 823-06-60

7. Lic. Feliciano Velásquez

Calle 3 S-n, Col. Aviación

Tel: 811-68-59

8. Lic. Rafael Nieto

Av. Salvador Nava \#7026

9. Manuel Muro

Galeana \#460

10 Casa de San Sebastián

Lerdo de Tejada \#3 Barrio de San Sebastián 


\section{Anexo 2}

\section{INVESTIGACIÓN ACADÉMICA SOBRE DIVERSIDAD CULTURAL}

Agradecemos su colaboración para responder este cuestionario.

Los datos que proporcione serán CONFIDENCIALES y los resultados globales, sin mencionar el nombre específico de esta biblioteca.

1.- ¿La misión de la biblioteca incluye la diversidad cultural?

SÍ $\mathrm{NO}$

2.- ¿Cómo está redactada la parte de la misión respecto a la diversidad cultural? 
Diversidad cultural y bibliotecas públicas

3.- ¿La biblioteca cuenta con una colección para atender las necesidades de información de las comunidades indígenas?

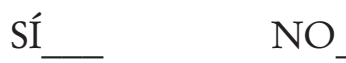

Características

4.- ¿La biblioteca cuenta con una colección bilingüe para apoyar la educación de niños y jóvenes indígenas?

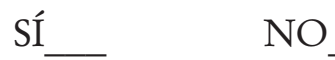

Características

5.- ¿La biblioteca cuenta con colecciones en lenguas extranjeras para apoyar las necesidades de información de las comunidades inmigrantes?

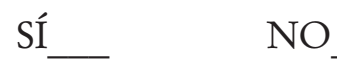


Diversidad cultural y acceso a la información

Características

6.- ¿La biblioteca tiene personal especializado para atender a comunidades indígenas y de inmigrantes?

SÍ

$\mathrm{NO}$

¿Cuántos?

Perfil

7.- ¿Cuáles son los servicios más frecuentes que solicitan las comunidades indígenas? 
Diversidad cultural y bibliotecas públicas

8.- ¿Cuáles son los servicios más frecuentes que solicitan las comunidades de inmigrantes?

9.-¿Qué actividades realiza la biblioteca para apoyar a las comunidades indígenas?

10.-¿Qué actividades realiza la biblioteca para apoyar a las comunidades de inmigrantes? 


\section{Anexo 3}

¿La misión de la biblioteca incluye

la diversidad cultural?

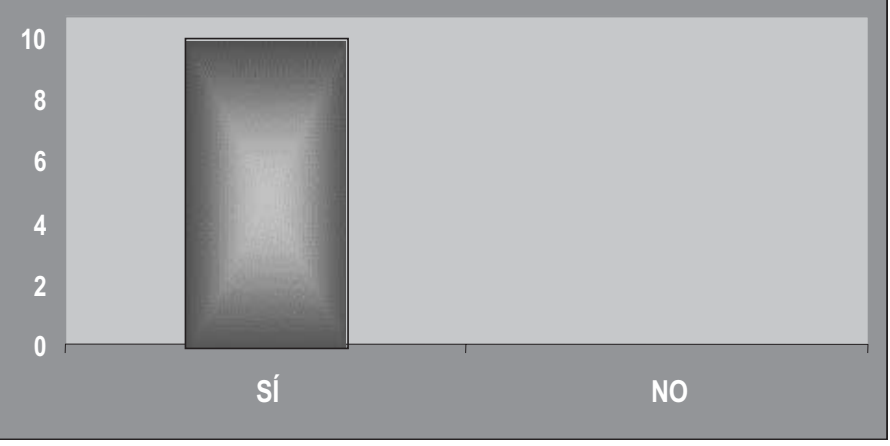

¿Cómo está redactada la parte de la misión respecto a la diversidad cultural?

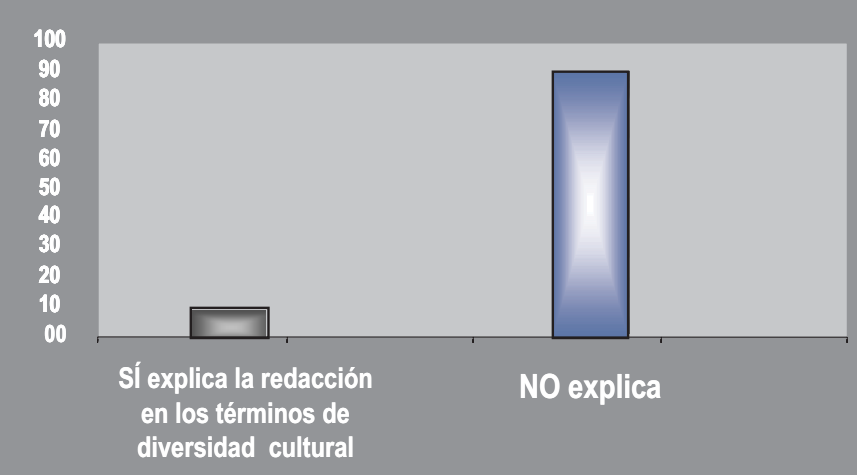


Diversidad cultural y bibliotecas públicas

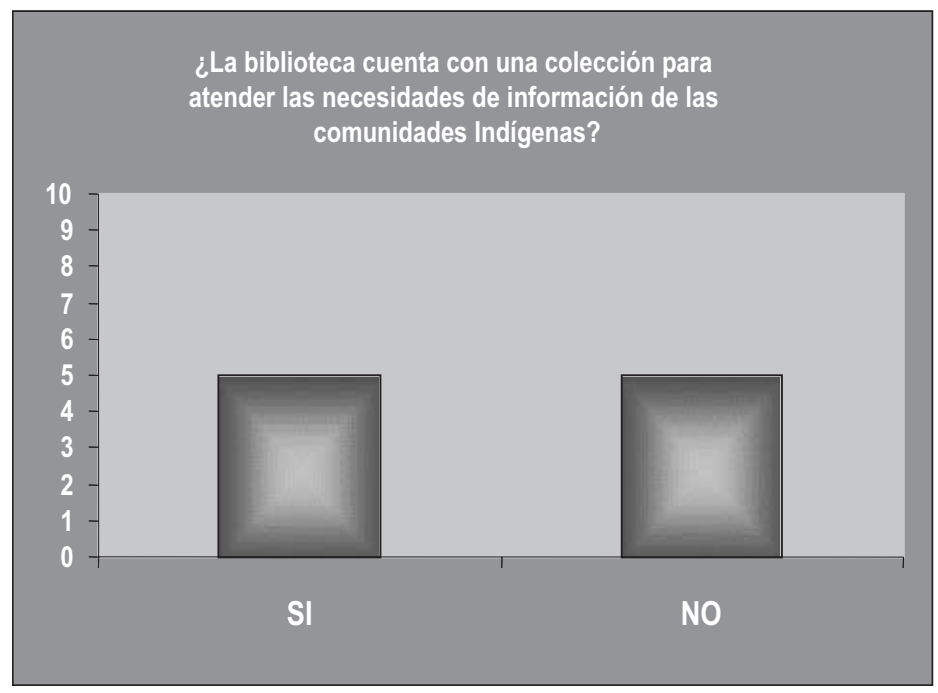

\section{Características de la colección}

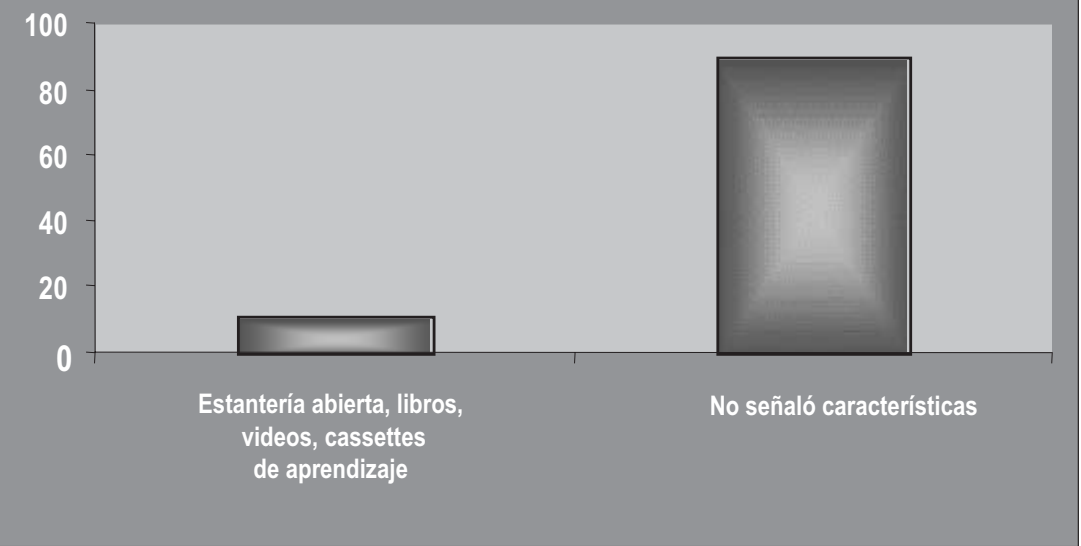




\section{Diversidad cultural y acceso a la información}

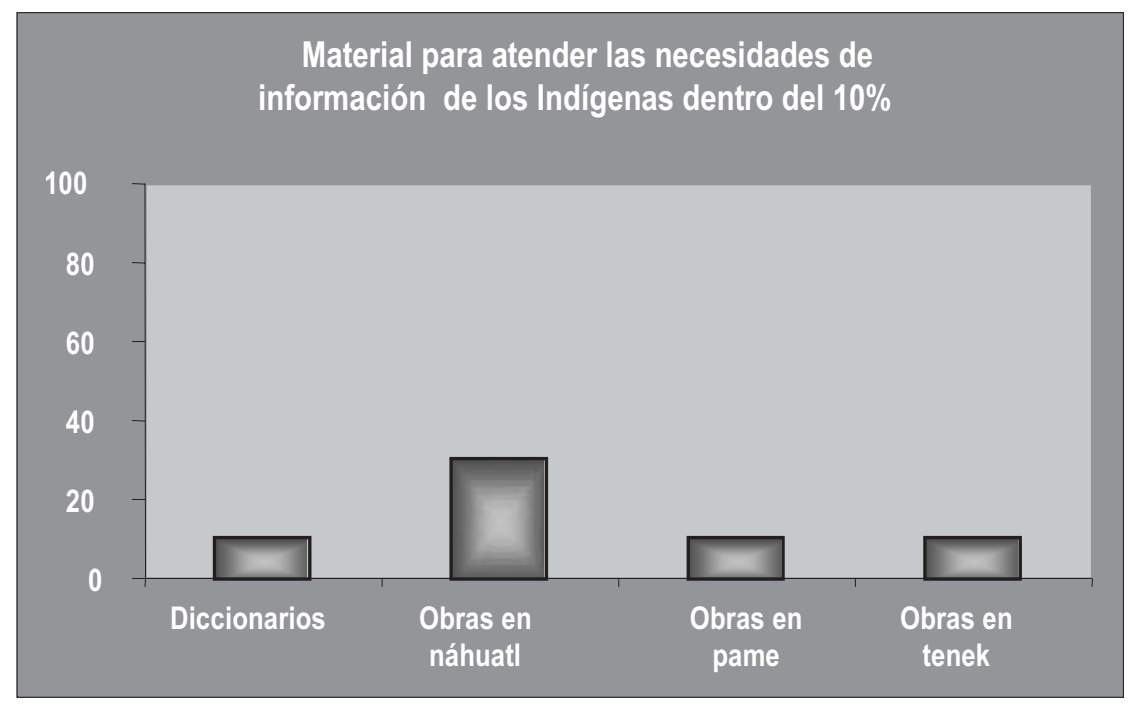

¿La biblioteca cuenta con una colección bilingüe para apoyar la educación de niños e

indigenas?

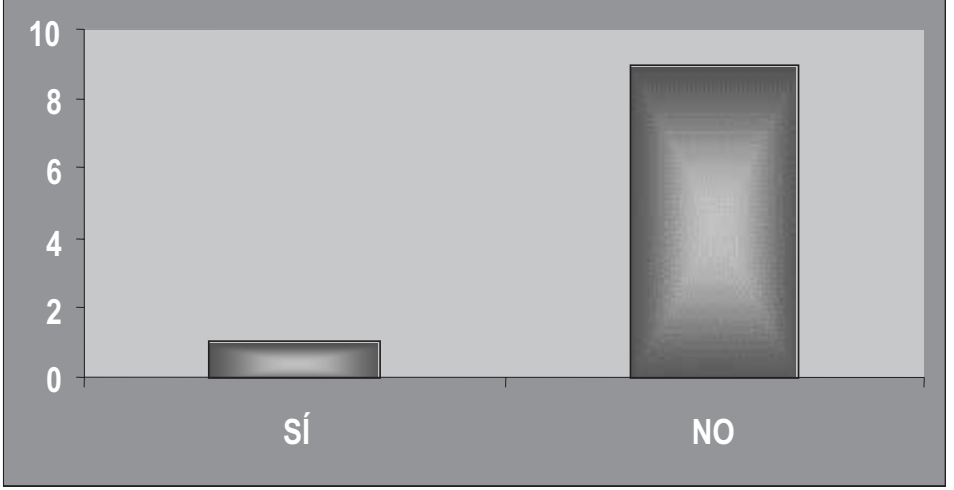


Diversidad cultural y bibliotecas públicas

\section{Características de la colección}
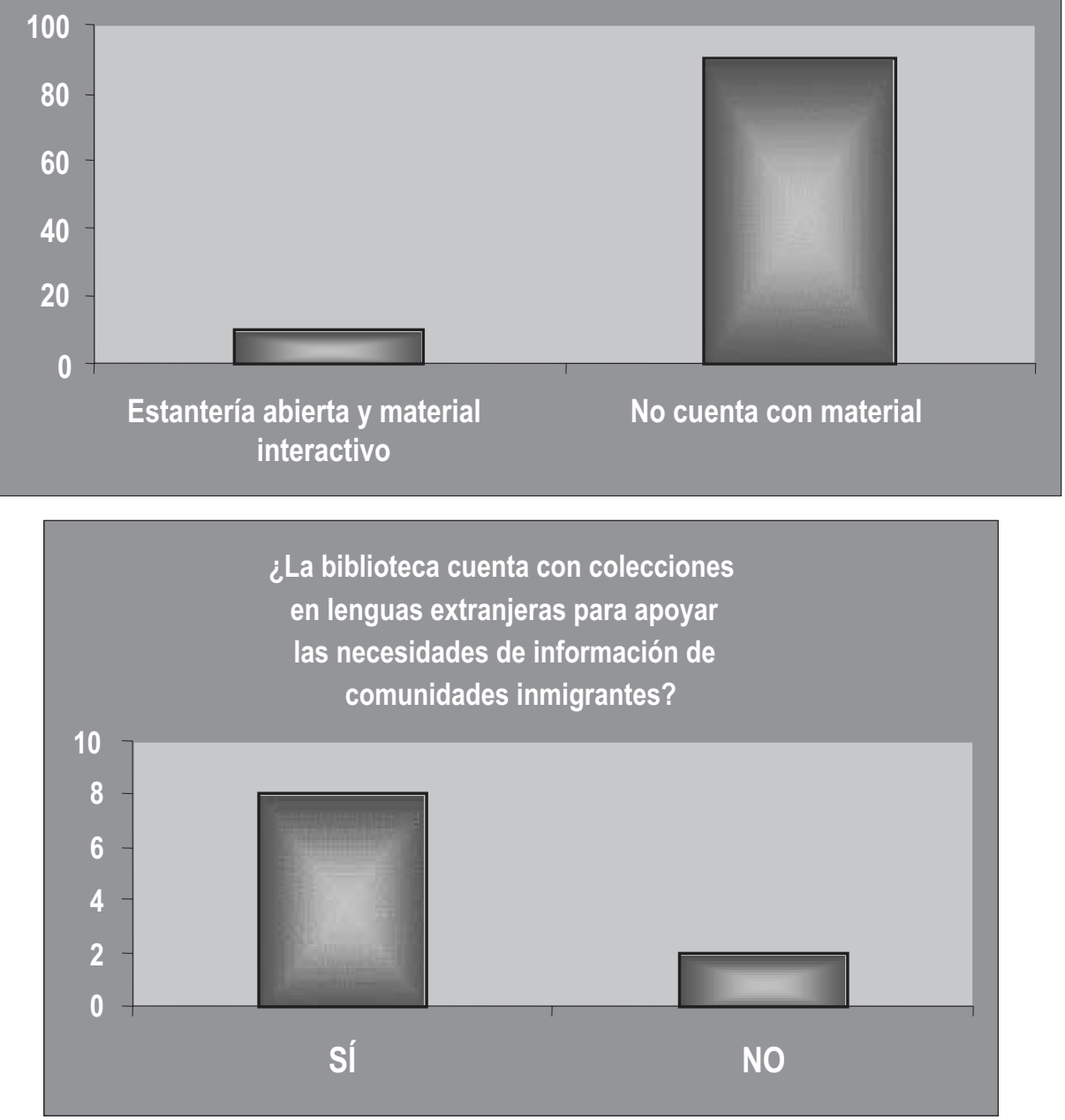
Diversidad cultural y acceso a la información

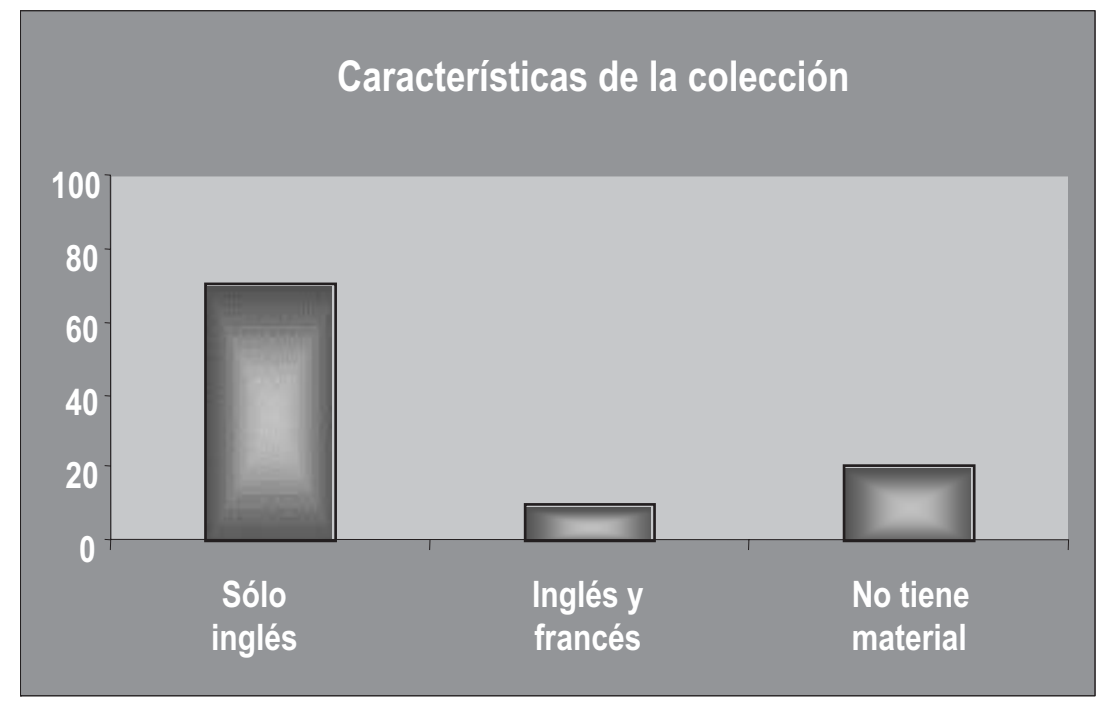

¿La biblioteca tiene personal especializado para atender a comunidades Indígenas y de inmigrantes?

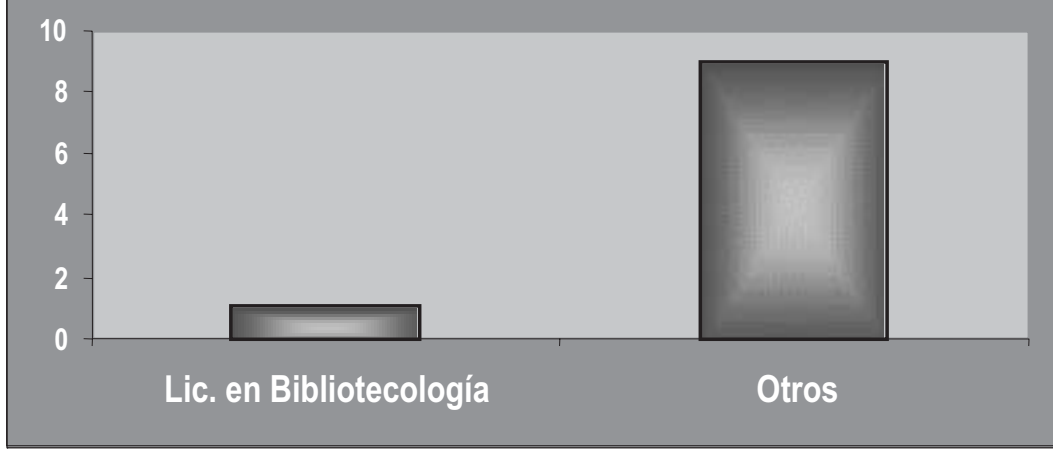


Diversidad cultural y bibliotecas públicas

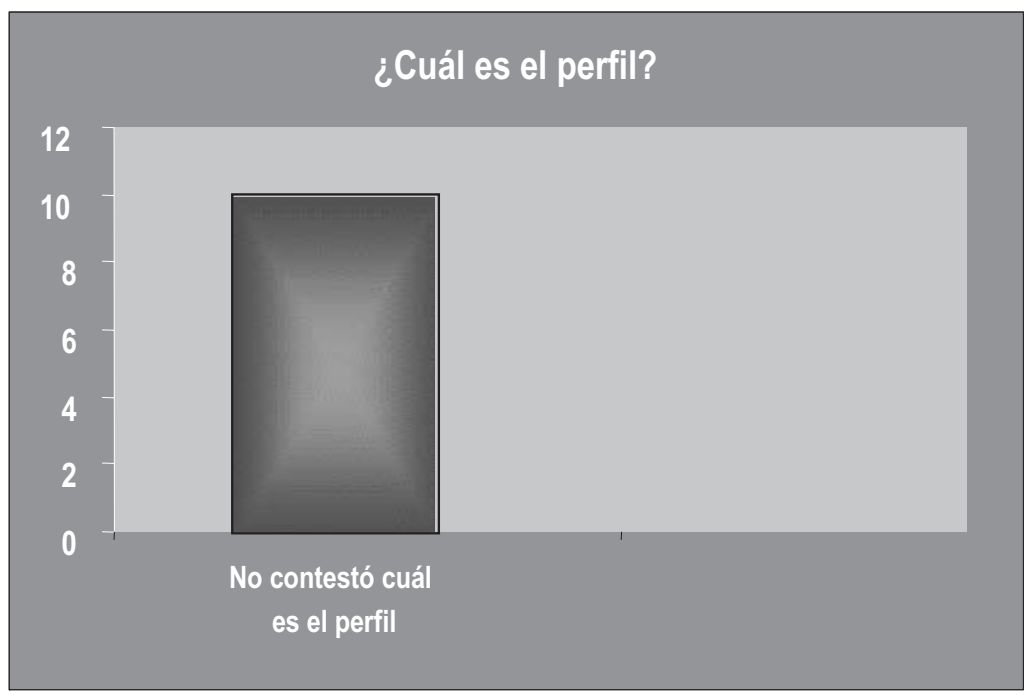

¿Cuáles son los servicios más frecuentes que solicitan las comunidades Indigenas?

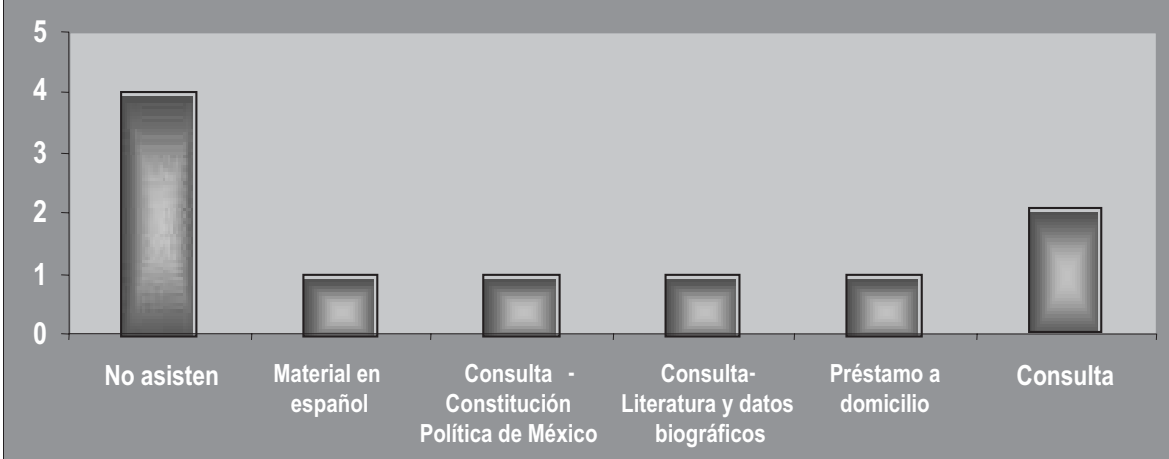




\section{Diversidad cultural y acceso a la información}
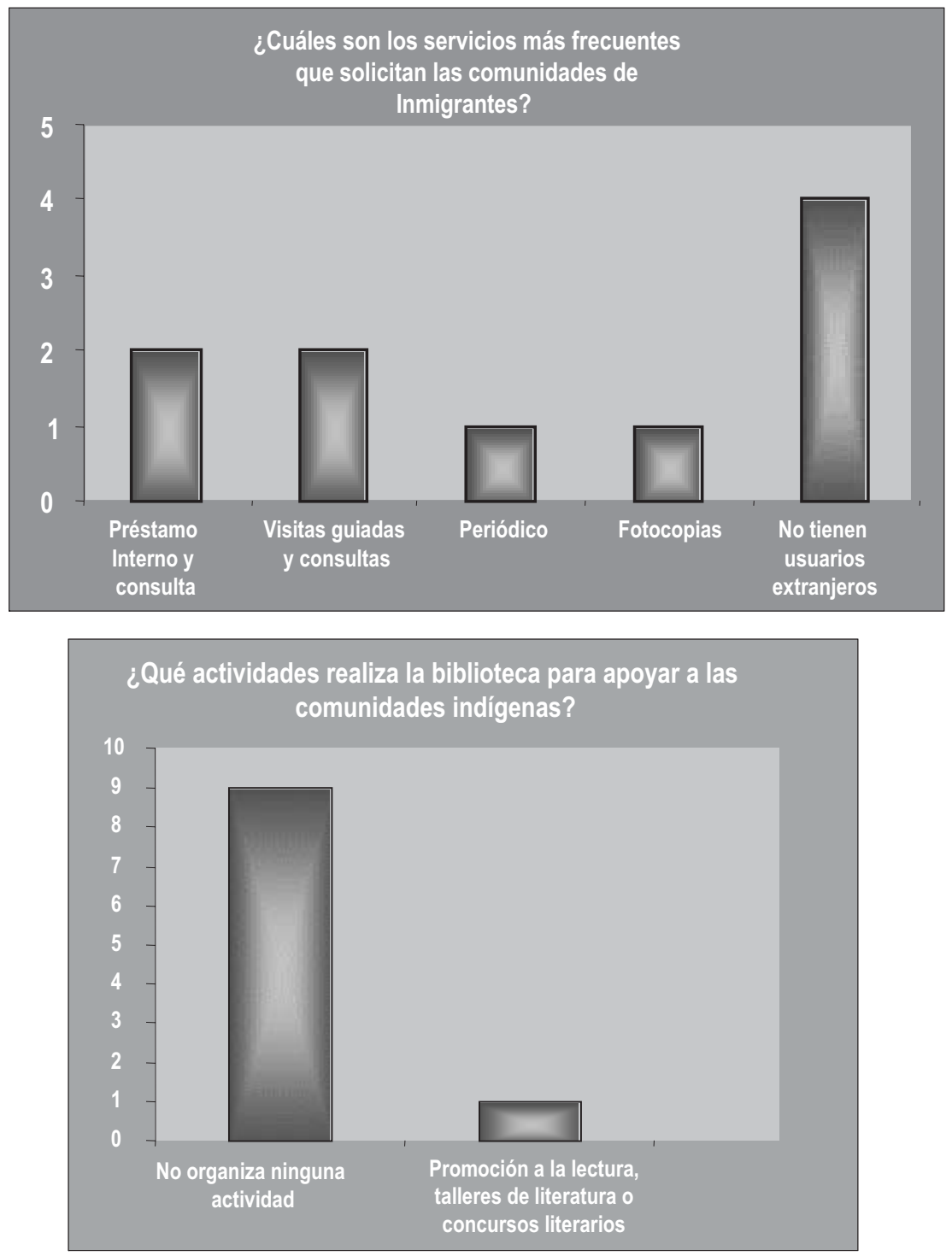
Diversidad cultural y bibliotecas públicas

¿Qué actividades realiza la biblioteca para apoyar a las comunidades de Inmigrantes?

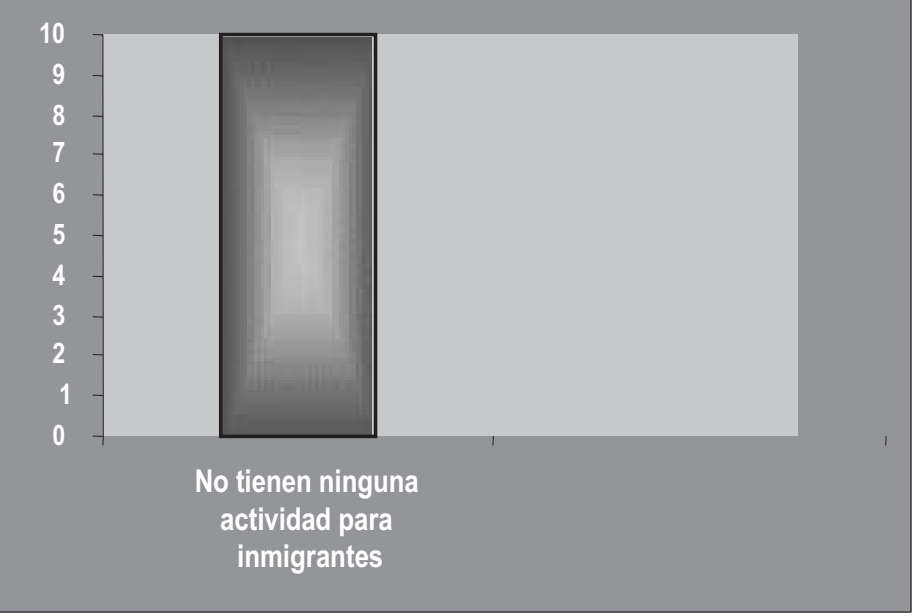


Diversidad cultural y acceso a la información

\section{Bibliografía}

Bayardo, R. "MERCOSUR, la diversidad cultural y la participación comunitaria", http://www.bioetica. org/bioetica/ensciciones19.htm (consultado el 3 de junio del 2006)

Clark, T. "Why we need Better Multiethnic Education?", Social Education, 42 (2):163-164, 1978.

Civallero, E. "Bibliotecas aborígenes" http://www. sagpya.mencon,gov,ar/new/0-0/forestacion/biblos /aborigenes.pdf·search =' Edgardo\%20Civallero\%20 bibliotecas\%20aborigenes (consultado el 5 de junio del 2006)

-- Culture, Language, and Society. California, Menlo Park, 1981.

"Declaración Universal de la UNESCO sobre la diversidad cultural", http://www.unesco.org/culture/plu$\mathrm{ralism} / \mathrm{diversity} / \mathrm{htm} / \mathrm{sp} /$ indexsp/shtlm (fecha de actualización, 25 de enero del 2002).

(Consultado el 10 de junio del 2006)

Díaz-Polanco, Héctor. "El conflicto cultural en el umbral del tercer milenio", http://www.memoria.com. $\mathrm{mx} / 131 /$ diazp.htm

(consultado el 15 de junio del 2006)

Ehlers, H. y Crawford, D., "Multicultural Education and National Unity", Educational Forum (47), 3: 263-277, 1983. 
Diversidad cultural y bibliotecas públicas

García Castaño, J., Pulido Moyano, R. A. y Montes del Castillo, A. "La educación multicultural", Revista Iberoamericana de Educación (13), 1997.

"La problemática de la diversidad cultural”, http://prodiversitas.bioetica.org/nota52htm (consultado el 7 de julio del 2006)

Lynch, J. Multicultural Education; principles and practice. London, Routledge, 1986.

Máiz, R. "Las ideologías nacionalistas contemporáneas: funcionalidad, estructura y tipología”. En: Mellón, J. A. Las ideas políticas en el siglo XXI. Barcelona, Ariel, 2002.

"Manifiesto de la UNESCO sobre la Biblioteca Pública", http://www.ifla.org/VII/s8/unesco/span.htm (última revisión, septiembre del 2004).

(Consultado el 8 de julio del 2006)

Pérez Gómez, A. I. La cultura escolar en la sociedad neoliberal. $3^{\text {a }}$ ed. Madrid, Morata, 2000.

Requejo, F. y Zapata-Barrero, R. "Multiculturalidad y democracia”. En: Mellón, J. A. Las ideas políticas en el siglo XXI. Barcelona, Ariel, 2002.

Sánchez, C. "Derechos de los pueblos Indígenas Originales y Migrantes", http://www.equidad.df.gob. $\mathrm{mx} /$ indigenas/seminario/02_mar_seguida_sanchez. htm (consultado el 12 de julio del 2006) 
Diversidad cultural y acceso a la información

Sleeter, C.E. Empowerment through Multicultural Education. New York, Suny, 1991.

Solomon, I.D. "Strategies for Implementing a Pluralistic Curriculum in the Social Studies", http://www.oei.org.co/oeivirt/rie13a09.htm 79 (6): 256-259,

1988. (Consultado el 17 de julio del 2006)

Stavenhagen, R. "Educación y derechos culturales: un desafío", http://catedradh.unesco.unam.mx/Puebla 2002extRStavenhagen.htm

(consultado el 20 de julio del 2006) 


\title{
Las sociedades multiculturales y su relación con la Bibliotecología
}

\author{
ESTEla MORAlES CAMPOS
}

【os cambios en la sociedad, la ciencia, la tecnoloLaía, la economía, el mercado, la política, los procesos democráticos, los derechos naturales y la legislación internacional, entre otras circunstancias, han influido y determinado el ciclo de la información: su generación, su organización y su uso. Todo ello obliga a plantear nuevos temas y nuevas áreas de estudio: el derecho de autor, el derecho a la información, la libertad intelectual, la sociedad de la información y del conocimiento, las políticas de información, la Internet, los motores de búsqueda, el open access (libre acceso), los repositorios electrónicos por tipo de material, el costo de la información, la lectura, la brecha digital, la equidad en costo y acceso y otros más. 
Asimismo, se tienen que tomar en cuenta elementos y circunstancias del mundo global que nos han permitido apreciar múltiples aristas de la cultura de cada uno de los países, así como el ir y venir de sus influencias, de sus mezclas, de sus aportaciones a las culturas locales y globales. Precisamente, tenemos que entender el ciclo de la información dentro de la multiculturalidad, la pluralidad y la diversidad de manifestaciones humanas, creencias e ideologías de pueblos que generan información y la usan.

\section{El respecto y la convivencia entre culturas: aspiraciones y realidades}

La globalización, que es un tema de nuestro tiempo y del pasado, va de la mano con una intensa y dinámica movilidad, de tránsito, de flujos humanos y de productos, de ideas y conocimientos que van y vienen en múltiples direcciones de manera física y virtual.

La globalización no es una totalidad geográfica e histórica, constituye una interacción entre espacios, épocas y hechos; entre sociedades que incorporan sus culturas y sus ideas, y suman y restan singularidades, particularidades y universalidades.

Cada espacio geográfico, el local o el global, está habitado por grupos humanos que han construido, desarrollado, formado sus propias culturas, las cuales se pueden multiplicar a través de mezclas y adi- 
Las sociedades multiculturales y su relación con la ...

ciones que han sido posibles por los desplazamientos de productos, ideas y creencias de los hombres que se han movido por el mundo conocido en cada una de las épocas que les ha tocado vivir.

Para tener un punto claro de referencia cuando hablamos de cultura en este documento, nos referimos al conjunto de rasgos espirituales, materiales, intelectuales y afectivos que caracterizan a un grupo social, además de los modos de vida, los sistemas de valores, tradiciones y creencias; en el sentido más amplio, la cultura incluye toda aportación humana que de manera original no nos dio la naturaleza, bien sea expresados en símbolos, productos, prácticas que pueden ser distintivos de estos grupos y suelen transmitirse en el tiempo y el espacio, de una generación a otra y de un lugar a otro. ${ }^{1}$

La movilidad y el flujo de personas o de sus creencias, ideas y productos, además de los movimientos migratorios, propician la comunicación y el enlace de culturas, lo que nos enfrenta a una realidad manifestada desde los orígenes de la humanidad, pero con una gran visibilidad en nuestros días:

1 Declaración universal de la UNESCO sobre la diversidad cultural, http://unesdoc.unesco.org/images/0012/001271/127160m.pdf; Guillermo de la Peña, cit. en: León Olivé, Multiculturalismo y pluralismo, México, Bs. As., Paidós-UAM-FFyL, 1999, p. 41. 
el multiculturalismo, la multiculturalidad y la interculturalidad.

La multiculturalidad, además de reconocer la diversidad de culturas y "la pluralidad de la razón $y$ del sentido a la vez de comprender la igualdad y diversidad de los sujetos", ${ }^{2}$ también abre el camino a esa interacción y mezcla de culturas, junto con la creación de espacios en que surgen nuevas expresiones que mezclan, conjuntan o integran manifestaciones de dos o más culturas para dar paso a la interculturalidad.

La realidad del multiculturalismo en el ámbito de la información y la Bibliotecología nos enfrenta a comunidades sociales, laborales, políticas, científicas y educativas, todas ellas multiculturales que requieren información en su vida cotidiana y profesional. En este sentido, la IFLA considera al multiculturalismo como la coexistencia de diversas culturas, ${ }^{3}$ entendiendo a la cultura en su forma más amplia, con base en la definición de UNESCO, es decir, incluye a los diversos grupos étnicos, religiosos y políticos que pueden manifestarse en una plu-

2 Luis Villoro, Estado plural, pluralidad de culturas, México, UNAM-FFyL- Paidós, 1999.

3 IFLA, "Definiendo "multiculturalismo", Informe final remitido por Clara M. Chu, Ekaterina Nikonorova y Jane Pyper, marzo 18, 2005, Library Services to Multicultural Populations Section: http://www.ifla.org/VII/s32/index.htm 
ralidad de comportamientos, creencias, ideas e ideologías, además de los diferentes estilos de comunicación.

El reconocimiento a la diversidad y a la pluralidad debería llevar implícito el deseo de la integración, no el de la atomización o el de la balcanización de los países, las regiones o el mundo; debe contemplar el pleno respeto y aceptación al otro, a la otra cultura, y no sólo a la tolerancia, que puede ser un principio endeble con tentación a la exclusión, lo cual echaría por tierra la convivencia en este mundo multicultural. En ese contexto, es necesario buscar caminos dirigidos hacia valores universales que permitan construir conductas que se socialicen y posibiliten la convivencia entre la diferencia para el logro de un bien común, en un país o en una región, lo cual nos hará más fuertes para vivir con los satisfactores necesarios y adecuados en un mundo local y global.

La biblioteca y los servicios de información tienen como insumo, precisamente, la información, es decir, un producto cultural de primer orden, ya que permite el registro de la diversidad cultural y la pluralidad de ideas, de pensamientos y de sensibilidades; por ello, tanto la Bibliotecología como los servicios de información se convierten en un medio ideal para la socialización de las expresiones 
culturales registradas en las colecciones bibliotecarias e informativas, ya sean impresas o electrónicas.

En consecuencia, la Bibliotecología tiene que estudiar el porqué y el cómo se pueden integrar estas diferencias expresadas en los productos culturales para tenerlas accesibles a comunidades que, a su vez, son multiculturales. Con base en la libertad intelectual y en el derecho a la información (principios que también asume y defiende la IFLA, al igual que otras asociaciones internacionales y nacionales como la ALA), los especialistas de la información deben propiciar y defender el derecho a la información para que éste se ejerza por todos los usuarios, pero también por los no usuarios, es decir, por todos los ciudadanos; además, es indispensable defender la libertad intelectual que favorezca la creación, las diferentes formas de ver e interpretar un hecho, una idea, y tener la posibilidad de que los creadores y los autores puedan ser conocidos, leídos, oídos por todo aquel interesado y que su curiosidad pueda ser satisfecha con una colección y por una institución que fomente la libertad intelectual y la infodiversidad.

\section{Los usuarios}

Para la Bibliotecología, todos los integrantes de un grupo social deben ser de interés o considerar que toda la población es potencialmente un usuario de información. Este usuario, este hombre o este ciu- 
Las sociedades multiculturales y su relación con la ...

dadano, ante la sociedad, tiene un compromiso como parte del grupo al cual pertenece.

En el campo de la información, los usuarios también tienen derechos y obligaciones; derechos como el de la información, el del libre acceso a los servicios de información producto de la libertad intelectual; el de acceder sin discriminación alguna y con equidad al saber, al conocimiento y a los servicios de información. Al mismo tiempo, tiene obligaciones, entre ellas, aunque parezca obvio, se encuentra el de ejercer tales derechos; por otro lado, tiene también la obligación de hacer posible que la pluralidad y la diversidad del multiculturalismo sean registradas en piezas informativas, que la infodiversidad en las fuentes impresas y electrónicas esté presente y sea visible.

La migración es un elemento muy importante en la integración multicultural y en la interculturalidad, ya que no sólo se desplazan las personas, sino que éstas van acompañadas de un gran equipaje cultural: lenguaje, ideas, creencias, valores, formas de vida y de comunicación, lo cual, a veces, ya está registrado en su lugar de origen, o bien, hay que registrarlo en el nuevo asentamiento; la Bibliotecología, en ese sentido, tiene que hacer énfasis en el registro, ya que ésa es la forma en que la información es objeto de estudio de dicha disciplina; como complemento, también lo es la lectura, ya que nos permite 
acercarnos al conocimiento de manera muy independiente del lugar y tiempo de su registro; además, la lectura conlleva una rica diversidad y pluralidad de ideologías, creencias y experiencias que se entrelazan con la diversidad y la pluralidad que registraron los autores.

La Bibliotecología ha tenido el reto de la multiculturalidad desde siempre, ya que las ideas, los manuscritos y los impresos han viajado en todo momento y, con las vías de comunicación, ese flujo de la información se incrementó. En épocas más recientes, las telecomunicaciones, la computación $\mathrm{y}$, ahora, las tecnologías de la información y la comunicación agilizaron y potenciaron la migración de la información. En este movimiento, la prensa, la radio, la industria editorial, la industria de la información, la televisión, la globalización de las señales de radio y televisión, han logrado que la cultura, vía la información escrita y audiovisual, se potencie de manera considerable y más intensa a partir de la Internet.

Con la popularización de las TICs (Tecnologías de la información y la comunicación), técnicamente cualquier usuario con acceso a éstas se encontraría en posibilidades de registrar información y, por supuesto, de tener acceso a toda la información que circule por la red o esté registrada con base a las TICs. 
Las sociedades multiculturales y su relación con la ...

Ahora, la comunidad de usuarios puede estar compuesta por una rica variedad de rasgos culturales que pueden proceder de: ${ }^{4}$

1. Los naturales actuales de la localidad.

2. Los naturales originales de la localidad.

3 . Los migrantes internos.

4. Otras minorías nacionales.

5. Los inmigrantes y sus descendientes.

6. Los refugiados y asilados por razones políticas.

7. Los residentes temporales por razones de estudio, trabajo o familiares.

8. Los pertenecientes a minorías que se distinguen por sus ideas, gustos, modos, profesiones, idiomas, etcétera.

9. Los grupos que asimilan más de una cultura que puede generar una nueva o no.

Históricamente se ha declarado que las bibliotecas tienen su razón de ser en función de la comunidad a la que pertenecen, ya sea la población en general, o una comunidad específica (científica, académica, escolar, obrera, etc.), pero en realidad pocas veces esta comunidad se había desagregado a partir de sus ingredientes culturales. Este componente puede determinar su perfil de usuario, por formación académica y personal y, por lo tanto,

4 La sección sobre servicios bibliotecarios para poblaciones multiculturales de la IFLA considera los numerales 3, 4, 5, 6. 
Diversidad cultural y acceso a la información

impactar en sus necesidades de información, en las formas de buscarla o en las fuentes preferidas por tradición o por conducta adquirida.

Respetar, promover y aceptar la rica diversidad que proviene del multiculturalismo y favorecer su registro fomenta la infodiversidad local y global. Esta infodiversidad obliga a todo ciudadano a promover la creación, difusión y circulación de ideas, pues de esa forma se les permite a los distintos grupos sociales tener un equilibrio de las diferencias y afinidades entre las regiones y bloques geográficos y entre grupos e individuos. ${ }^{5}$

\section{El bibliotecario y los servicios de información}

Reflexionar sobre el papel que deben jugar en la sociedad el bibliotecario y los servicios de información es urgente, porque el multiculturalismo es una realidad. Cada uno de los hombres cada vez está más consciente de que no hay un solo grupo cultural que se asuma como el patrón o modelo, como en los siglos en que el eurocentrismo dominó los cánones y modelos mundiales, sino que, hoy día, todos podemos aportar algo a la cultura universal y

5 Estela Morales Campos, La diversidad informativa latinoamericana en México, México, UNAM/CCYDEL, 2001. p. 40 
Las sociedades multiculturales y su relación con la ...

considerar que una forma diferente de ver la vida con respecto a otra es válida y, por lo tanto, es posible ver la diferencia como una riqueza, no como una deficiencia.

Muchas veces, los servicios de información que diseña y ofrece el bibliotecario se ven impactados por la relación de dos factores: el número de usuarios y el presupuesto; los más afortunados agregan como factor fundamental la calidad o la alta calidad para cada uno de sus usuarios. En la medida en que detectamos más diversa a la comunidad, todos nuestros procesos se pueden masificar menos, transitando a una atención más personalizada, no necesariamente individualizada, pero sí dirigida a pequeños grupos de usuarios con características afines que reflejen la diversidad y pluralidad de su comunidad. Esta diferenciación es posible en los centros de investigación, donde una atención más individualizada es una realidad, en función del número de investigadores que atienden y de la dotación presupuestal generosa que normalmente tienen; una biblioteca universitaria tiene la práctica de dividir a su comunidad por carrera, por disciplina, por grado, y ahora, además de estos elementos, deberá tomar en cuenta los ingredientes de una comunidad multicultural, no sólo por sus estudiantes inscritos in situ y su planta formal de profesores e investigadores, sino también por la diversidad de su 
comunidad académica y estudiantil virtual que consulta su colección en la Red. Una biblioteca pública también ha considerado la diversidad de su comunidad a partir de la edad y las actividades productivas de su comunidad predominante, pero no necesariamente ha tomado en cuenta los elementos de una sociedad multicultural, como los diferentes idiomas, las maneras de comunicación, los valores, las ideologías, la historia y la actualidad de diferentes pueblos y culturas que dan raíces a los usuarios de este tipo de bibliotecas.

Tomar en cuenta estas necesidades de la actualidad convulsionada de nuestro mundo, muchas veces por diferencias ideológicas, religiosas o étnicas, ayudaría al desarrollo de una sociedad más armoniosa, con menos conflictos, que, con mejor entendimiento del otro y el respeto del principio de aceptación de otras posturas, de otras ideas y sensibilidades, evitaría muchas agresiones y confrontaciones bélicas y facilitaría las relaciones humanas, laborales, políticas e internacionales.

Si bien lo hasta aquí expresado se tiene que considerar como una posición de principios fundamentales de la Bibliotecología y un tema para políticas de información, tenemos que observar la práctica profesional en el mundo real y tener muy claro que, para llegar de manera focalizada a estos grupos multiculturales, se requerirá reorganizar las funcio- 
Las sociedades multiculturales y su relación con la ...

nes y procesos de la biblioteca y reordenar, entre otras cosas, las tareas del personal; así, ante nuevas tareas, quizá nuevas colecciones y servicios, se tendrá que tener un respaldo presupuestal.

Algunos cambios que se tendrán que realizar deberán partir del conocimiento de la comunidad para conocer la diversidad de nuestros usuarios y sus necesidades de información. Lo que necesariamente impactará en el desarrollo de colecciones, que no sólo buscará nuevos títulos, sino que buscará un nuevo diálogo entre proveedores, bibliotecólogos y usuarios o con fuentes que reflejan los intereses y necesidades de la multiculturalidad.

La organización de la colección impresa o electrónica tiene que propiciar una conexión entre el usuario y el contenido de cada pieza informativa, donde el lenguaje, las formas y giros idiomáticos son muy importantes para que el usuario final pueda comprender el código internacional usado en el registro y en la recuperación de la información.

Una vez resuelta la organización de la información, es necesario considerar los principios que han sustentado a la Bibliotecología y la guían hoy en la globalización con la potencialidad de las telecomunicaciones. Las vías de comunicación, la TIC’s, la creatividad y la imaginación del hombre impactan de frente reafirmando los principios básicos y adoptando de forma más aplicada que declarativa 
otros que se derivan de la propia sociedad y del reconocimiento de la sociedad multi e intercultural, con su diversidad y pluralidad abierta, no escondida, no subterránea, no prohibida.

La Bibliotecología constituye una disciplina que tiene su razón de ser en la sociedad y en el hombre que crea el conocimiento y lo registra; $y$ tal conocimiento hoy se toma como el motor que mueve y desarrolla a la sociedad, al grado de llamarla sociedad de la información y del conocimiento; al respecto, hay que plantearse fuertes interrogantes:

a) Cómo promover el uso de la información con respeto a diferentes creencias, ideas, ideologías, idiomas y culturas.

b) Cómo garantizar la equidad en el acceso a la información.

c) Cómo ser un agente facilitador de la participación democrática en la sociedad a partir de la información.

Y como el hacedor de realidades sería el especialista en información, el bibliotecario tiene que reeducarse, tiene que hacer un aprendizaje de las nuevas dinámicas socio-políticas que mueven al mundo y tiene que reconsiderar las funciones y los procesos bibliotecológicos, cómo obtener la información requerida y ofrecerla al usuario final, tomando en cuenta las nuevas demandas de la socie- 
Las sociedades multiculturales y su relación con la ...

dad y el surgimiento de exigencias y derechos de valor universal.

Los aspirantes a desarrollarse profesionalmente en este campo, como los estudiantes, deberán hallar estos enfoques en sus planes de estudio y cursos formales, pues el que ya es practicante tomará el camino de la actualización, la capacitación y la educación continua.

Estos programas educativos, entre sus objetivos, deben generar un cambio de actitud entre los profesionales en servicio y entre los estudiantes, porque la sociedad civil ya ha iniciado el cambio al fomentar valores de respeto, tolerancia y plena aceptación del otro.

\section{La educación y la investigación bibliotecológicas}

La aparición de sociedades complejas multiculturales no es reciente, sino que éstas se han ido formando desde los orígenes de los grupos humanos y siempre ha existido la posibilidad de la interculturalidad; sin embargo, lo que no ha sido fácil ni se ha dado de manera cotidiana es la convivencia de los distintos grupos, el reconocimiento de esta realidad y el respeto al otro; esta actitud no se ha formado ni en la familia, ni en la escuela, ni en la sociedad en general, aunque de manera natural las sociedades de hoy sean multiculturales. 
Ante esta realidad, hoy más que nunca, la Bibliotecología y la investigación que se hace en el área tiene que auxiliarse de otras disciplinas sociales, como la propia sociología, la antropología, la ciencia política, la comunicación, el derecho y la filoso$f^{\prime}$ á, entre otras, para dar una respuesta adecuada a muchas preguntas de investigación que puedan ofrecer soluciones a la problemática social de la información y la práctica bibliotecaria, las cuales, a su vez, interactúan con otros cuestionamientos técnicos y tecnológicos que hoy son parte integral del comportamiento y del ciclo de la información.

También se tiene que abordar el trabajo multi e interdisciplinario, porque la información se genera y se usa en una multiplicidad de ambientes y en una diversidad de necesidades provenientes de seres humanos igual de diversos y plurales. Esta información no necesariamente se usa en la biblioteca o en otras instituciones sociales tradicionalmente relacionadas con la información, sino en cualquier espacio y en cualquier momento, a partir de las telecomunicaciones, las TIC's, la radio, la televisión o el Internet.

Entre los temas relacionados con el multiculturalismo y la diversidad que hoy se tienen que abordar por estos equipos plurales podríamos citar, sin priorizar:

- La sociedad del conocimiento y la sociedad del desarrollo. 
Las sociedades multiculturales y su relación con la ...

- La libertad intelectual y el acceso al conocimiento.

- Derechos y participación de diferentes grupos culturales, lingüísticos y étnicos.

- Interacción de grupos heterogéneos y convivencia entre mayorías y minorías.

- El derecho a la información y elementos que afectan su uso.

- La lectura y el lenguaje como llave de acceso al conocimiento.

- La alfabetización informativa en usuarios culturalmente diversos.

- La visibilidad de la información local y global.

- La migración de grupos sociales creadores y usuarios de información.

- El multiculturalismo y la pluralidad informativa.

- Servicios comunitarios de información.

- La equidad de costos y acceso.

Por supuesto que la lista no es exhaustiva, pero cada colectivo de docencia e investigación incluirá o desechará temas más relacionados con sus objetivos y requerimientos.

Cada vez más, los centros académicos tienen una representación más plural y diversa en sus integrantes, profesionales, investigadores y alumnos; por lo tanto, el enfoque multicultural y de diversidad y pluralidad estará en el entorno cercano y lejano. Sobre todo, si tomamos en cuenta que el trabajo profe- 
sional del bibliotecólogo está enfocado cada vez más a una comunidad que claramente tiene dos componentes que sobresalen: rasgos locales y perfiles internacionales y globales que se representan evidentemente en las demandas de información.

Esta situación se ve como causa y efecto de la movilidad y la tendencia a la internacionalización de los estudiantes, de sus universidades y planes de estudio; lo mismo podríamos decir de la práctica profesional del mercado de trabajo vinculado a ofertas de empresas con normas internacionales combinadas con adecuaciones locales que permiten un flujo constante de profesionales y mano de obra en general.

Si bien siempre encontraremos una cultura dominante, habrá que reconocer espacios para otras manifestaciones culturales que propicien la interculturalidad, como lo es la biblioteca; así, cada vez más, el perfil del bibliotecólogo será el de un ciudadano del mundo que tenga que desarrollar las capacidades necesarias para una fácil comunicación con ese mundo del cual forma parte y con el que todos los días se comunica en variadas formas. Los programas de educación tienen que formar estudiantes provenientes de la interculturalidad para desarrollarse en servicios de información que, las más de las veces, responderán a comunidades reales o vir- 
Las sociedades multiculturales y su relación con la ...

tuales que representan intereses multiculturales plurales y diversos.

La investigación bibliotecológica debe provocarnos la curiosidad y, en la medida de lo posible, brindarnos respuestas sobre el porqué, el cómo, el cuándo, el para quién y el para qué de temas inherentes a la Bibliotecología, sin olvidar tres actores fundamentales: los usuarios, los bibliotecólogos y las colecciones informativas; cada uno de ellos forman subconjuntos que llevan consigo sus tradiciones, ideologías e imágenes, relacionadas con un pasado y un presente lleno de intercambios plurales y diversos en busca de equilibrio.

\section{Bibliografía}

García Canclini, Néstor. Diferentes, desiguales y desconectados. Mapas de la interculturalidad. Barcelona, Edit. Gedisa, 2004.

Garduño Vera, Roberto. "Reflexiones en torno al Centro Universitario de Investigaciones Bibliotecológicas, a sus 25 años de existencia”, p. 27-38, en: Ceremonia Conmemorativa, XXV aniversario del CUIB. México, UNAM/CUIB, 2007 (Cuadernos Conmemorativos, I) 
Diversidad cultural y acceso a la información

IFLA. "Definiendo "multiculturalismo", Informe final remitido por Clara M. Chu, Ekaterina Nikonorova y Jane Pyper, marzo 18, 2005, Library Services to Multicultural Populations Section: http://www.ifla.org/VII/s32/index.htm

IFLA. "Servicios Bibliotecarios Multiculturales", Sección sobre Servicios Bibliotecarios para Poblaciones Multiculturales, "Raison d'être des services multiculturels de bibliothethèque [Spanish], http://www.ifla.org/VII/s32/index.htm

Mireles Cárdenas, Celia. "Las bibliotecas ante la información multicultural de las sociedades globales y locales”, p. 41-52, en: Morales Campos, Estela (coord.). El multiculturalismo y los servicios de información. México, UNAM/CUIB, 2007 (Sistemas Bibliotecarios de Información y Sociedad).

Morales Campos, Estela. "Cuarenta años de formación de bibliotecólogos y la investigación bibliotecológica”, p. 157-171, en: Licea de Arenas, Judith (coord.). Cuarenta y cinco años de estudios universitarios en Bibliotecología: visiones empíricas e históricas. México, UNAM-FFYL, 2001 (Colección Jornadas).

---. La diversidad informativa latinoamericana en México. México, UNAM/CCyDEL, 2001.

---."La investigación bibliotecológica, una rica historia y un futuro prometedor", p. 39-48, en: Ceremonia Conmemorativa, XXV aniversario del CUIB. México, UNAM/CUIB, 2007 (Cuadernos Conmemorativos, I). 
Las sociedades multiculturales y su relación con la ...

Peña, Guillermo, cit. en: Olivé, León. Multiculturalismo y pluralismo. México, Bs. As., Paidós- UAM-FFYL, 1999, p. 41.

Ríos Ortega, Jaime. "Multiculturalismo, diversidad cultural y educación bibliotecológica: un tema fundamental de la agenda", p. 69-81, en: Morales Campos, Estela (coord.). El multiculturalismo y los servicios de información. México, UNAM/CUIB, 2007 (Sistemas Bibliotecarios de Información y Sociedad).

Schrader, Alvin M. Toward a Theory of Library and Information Science, Indiana, Indiana University, Thesis Ph. D., 1983, vol. 1.

UNESCO. Declaración universal de la UNESCO sobre la diversidad cultural, http://unesdoc.unesco.org/images/0012/001271/127160m.pdf

Villoro, Luis. Estado plural, pluralidad de culturas. México, UNAM/FFyL- Paidós, 1999. 


\section{Acuerdos de investigación. Seminario permanente "Bibliotecología, Información y Sociedad"}

HOMERO QUEZADA PACHECO

\section{Participantes:}

- Maestra Beatriz Casa Colegio de Bibliotecología de la Facultad de Filosofía y Letras de la UNAM)

- Licenciado Hugo Figueroa Colegio de Bibliotecología de la Facultad de Filosofía y Letras de la UNAM

- Maestra Celia Mireles Escuela de Ciencias de la Información de la Universidad Autónoma de San Luis Potosí

- Maestra Rosa María Martínez Rider Escuela de Ciencias de la Información de la Universidad Autónoma de San Luis Potosí

1 Efectuado el 26 de marzo de 2007 en la Escuela de Ciencias de la Información de la Universidad Autónoma de San Luis Potosí, en el marco de la XIX Semana de Ciencias de la Información: "Multiculturalismo y patrimonio documental". 
Diversidad cultural y acceso a la información

- Licenciado José de Jesús Hernández

Escuela Nacional de Biblioteconomía y Archivonomía

- Doctora Estela Morales

Centro Universitario de Investigaciones Bibliotecológicas de la UNAM

- Doctor Jaime Ríos

Centro Universitario de Investigaciones Bibliotecológicas de la UNAM).

\section{Multiculturalismo y educación}

Se analizó el documento "Comunidades multi$\checkmark$ culturales. Directrices para el servicio bibliotecario" de la IFLA, así como puntos específicos de la Ley General de Bibliotecas prevaleciente en el país (sobre todo los incisos IV y V del Artículo $7^{\circ}$, relativos a las colecciones y acervos de las bibliotecas públicas que deben satisfacer necesidades culturales, educativas y de desarrollo en general).

Se sugirió que el seminario se podría ocupar de ciertas líneas de trabajo que combinaran el multiculturalismo, la sociedad y la información, como, por ejemplo: a) las relacionadas con lo conceptual (multiculturalismo con información; multiculturalismo con bibliotecas, etc.); b) las vinculadas con la normativa; c) las relativas a la educación en cuanto a los contenidos de cursos curriculares y de investi- 
gación; d) las concernientes a las nuevas tecnologías de la información, etc.

Se resaltó el aspecto asociado a la educación, porque ésta, se consideró, es la base de una importante reflexión para que, eventualmente, surja una temática que el seminario sugiera a las escuelas y, de ser posible, la tomaran en cuenta en las asignaturas. Se propuso que el desarrollo de un tema como el de multiculturalismo dentro del los programas de educación se incluyera en la lista de puntos a desarrollar por el seminario. Los avances de cada trabajo podrían ser presentados al seminario para su discusión y enriquecimiento.

Se indicó que otros temas que podrían añadirse son los de género y grupos emergentes. Se planteó abordar el estudio de la normatividad existente en diversos organismos y asociaciones bibliotecarias así como los logros de bibliotecas públicas y los temas de valores y el desarrollo de colecciones.

\section{Análisis del documento "Comunidades multiculturales"}

Se indicó que éste no constituye una serie de normas, sino, como su nombre lo indica, se trata de guías. Se destacó el párrafo relativo a que las minorías no se planteen como independientes a los servicios "normales" y el punto referente a la equidad como un elemento destacable en la multiculturalidad. 
Del apartado titulado "Diversidad étnica, lingüística y cultural" se expuso que, en México, tienen relevancia las minorías nacionales. Se vertieron comentarios en torno a las particularidades del uso de la lengua por niños, jóvenes y grupos sociales diversos, para analizar la manera en cómo se acercan a la información.

Se propuso agregar el tema de la sociedad civil en la lista de puntos a desarrollar individualmente; la sociedad civil, se especificó, está diversificada en grupos culturales que reclaman una identidad para hacerse presentes; sin embargo, el documento de IFLA examinado parece estar elaborado desde una perspectiva eurocentrista, pues no contempla plenamente los grupos étnicos originarios ni la multiculturalidad característica de países como el nuestro (o como los latinoamericanos en general). Se añadió que es importante abordar el hecho de cómo el bibliotecólogo afronta el reto de formar parte de procesos fundamentales que se dan en circuitos de información de grupos sociales pertenecientes a minorías o a individuos de culturas alternativas. Se matizó, sin embargo, que ese tema es muy amplio y que, para investigar en torno a los circuitos de información de tales grupos, es necesario conocer a las comunidades específicas y tener en cuenta la diversidad ideológica que se refleja de ese espectro. 


\section{Comunidades indígenas y migración}

Acerca de la "Interpretación" de las Directrices, se indicó que los aspectos considerados en ese apartado se pueden equiparar a algunos de los desafíos que enfrentan las bibliotecas públicas en México, como, por ejemplo, el relacionado con la información registrada en lenguas indígenas.

Se ejemplificó el caso de TV UNAM, que transmite una valiosa programación en donde se resalta el hecho de que es imprescindible que las comunidades indígenas sigan preservando su cultura y que, al mismo tiempo, se integren al desarrollo nacional. Se puntualizó, sin embargo, que una es la perspectiva académica de lo que debe ser y otra es la dura realidad que viven esos grupos sociales, pues a veces las necesidades de éstos los conducen a decisiones que no siempre coinciden con los puntos de vista de los que estudian esas culturas desde fuera, como muchos enfoques académicos. Ése es el caso de las migraciones indígenas a Estados Unidos: algunos grupos indígenas, antes de aprender el idioma español, optan por aprender el inglés, porque éste les ofrece la oportunidad de tener un contacto cultural más cercano con el nuevo entorno en el cual se establecen. Se comentó la responsabilidad gubernamental en ese fenómeno y se discutió cómo, en el país, se encuentra arraigada una cultura de la migración que, en muchas ocasiones, prevé el 
traslado de muchos individuos a Estados Unidos, donde encuentran mejores oportunidades para su sobrevivencia y desarrollo.

\section{Compromiso social}

Al relacionar lo anterior con el documento de IFLA, se indicó que un elemento fundamental de las directrices es el de la equidad. Los servicios equitativos, se dijo, constituyen una de las preocupaciones centrales de la disciplina y se planteó la pregunta de qué manera es posible hacerlos eficientes. Se opinó que una tendencia al respecto es la movilidad y estimulación de grupos independientes (como los estudiantes que, por iniciativa propia, trabajan con grupos étnicos en zonas rurales). Se enfatizó que es importante promover y alentar esas iniciativas en los bibliotecólogos de todo el país, porque las manifestaciones que existen son aisladas y carecen de apoyo oficial. Se recalcó la importancia de promover esa conciencia en los alumnos a través de la reformulación de los planes estudio, concentrados en aspectos tecnológicos y operativos, pero deficientes en valores de servicio social. Se manifestó una postura crítica al respecto porque, en realidad, se dijo, la formación de los bibliotecarios insistía muy poco en el compromiso social. Se coincidió en señalar que, más que los rasgos tecnológicos en la dis- 
Acuerdos de investigación. Seminario permanente ...

ciplina, es necesario considerar en las asignaturas la axiología, la ética y los valores.

\section{Conclusiones}

Las conclusiones de la reunión se concentraron en dos ejes: a) a partir del listado de temas tentativos, se añadirían las propuestas vertidas en esa ocasión para elaborar una próxima publicación (cada miembro del seminario podrá elaborar un capítulo específico del tema de su interés); b) se constató que el tema relativo a la educación es un aspecto de gran relevancia. La siguiente actividad del seminario, por lo tanto, se dirigirá a elegir un tema a partir de la lista ampliada y comenzar a esbozar una línea de trabajo (se consideró válido que algún tema de importancia fuera abordado por más de un miembro del seminario). Se propuso trabajar sobre el tema de planes de estudio y esbozar una presentación de un curso teórico-práctico sobre el compromiso social del bibliotecario, el multiculturalismo y los servicios bibliotecarios. 
Diversidad cultural y acceso a la información. La edición consta de 150 ejemplares. Coordinación editorial, Zindy E. Rodríguez Tamayo. Formación editorial, Carlos Ceballos Sosa. Revisión especializada, Homero Quezada Pacheco. Centro Universitario de Investigaciones Bibliotecológicas/ UNAM. Fue impreso en papel cultural ahuesado de 90 gr. en los talleres de Producciones Editoriales Nueva Visión, ubicados en Juan A. Mateos, número 20, Col. Obrera, México D. F. Se terminó de imprimir en el mes de julio de 2009. 